\title{
Stabilitas Struktur Candi Mendut
}

\author{
Structural Stability of Mendut Temple \\ Fransiska Dian Ekarini, Joni Setiyawan, Winda Diah Puspita Rini, \\ Pramudianto Dwi Hanggoro dan Ahmad Mudzakkir \\ Balai Konservasi Borobudur \\ fransiscadian79@gmail.com
}

\begin{abstract}
ABSTRAK
Kajian Stabilitas Struktur Candi Mendut ini sangat penting guna mengevaluasi kondisi stabilitas struktur bangunan Candi Mendut sehingga kelestariannya akan terjaga. Berbagai kegiatan yang dilaksanakan dalam rangka kajian ini meliputi analisis data monitoring pengukuran kemiringan dinding candi dan kerenggangan nat batu candi, eksakavasi/penggalian arkeologi dalam rangka melihat struktur pondasi bangunan candi, melakukan pengukuran penggelembungan dinding candi, analisis daya dukung tanah halaman, dan penelusuran foto-foto lama.
\end{abstract}

Metode yang digunakan dalam penelitian ini adalah observasi lapangan, pengumpulan data primer dan sekunder, focus group discussion dan analisis data. Hasil kajian menunjukkan bahwa berdasarkan analisis data monitoring pengukuran kemiringan dinding didapatkan hasil bahwa terjadi pergerakan kemiringan pada titik-titik pengamatan paling besar 4 detik. Sedangkan selama periode dua tahun ini terjadi penambahan kerenggangan nat batu candi berdasarkan data crackmeter yang dipasang pada nat batu. Berdasarkan ekskavasi ternyata struktur pondasi candi hanya terdiri dari satu lapis batu dan terdapat lapisan mortar sebagai penguat tanah pondasi. Perhitungan daya dukung tanah di halaman candi menunjukkan bahwa tanah di sekitar Candi Mendut masih baik untuk mendukung bangunan candi di atasnya. Besarnya penggembungan dinding candi sisi tenggara adalah maksimal $4 \mathrm{~mm}$ berdasarkan hasil pengukuran menggunakan 3D Laser Scanner. Sampai dengan saat ini belum ada pedoman tentang kemiringan dinding pada bangunan candi, sehingga perlu dibuat pedoman sehingga dapat menjadi perbandingan untuk pengukuran selanjutnya. Hasil penelusuran foto-foto lama Candi Mendut menunjukkan bahwa pemugaran pertama terdiri dari beberapa tahap, tidak ditemukan adanya foto pembongkaran total candi, dan ternyata di dalam struktur kaki candi terdapat struktur bata yang belum diketahui selama ini.

Untuk menganalisis kondisi stabilitas struktur khususnya Candi Mendut, tentu saja kurang valid apabila hanya dilakukan dengan data selama tahun berjalan 2018, apalagi dengan keterbatasan data-data referensi tentang pemugaran sebelumnya. Data tahun 2018 ini akan menjadi baseline atau data dasar untuk kegiatan monitoring/pemantauan ke depan sehingga bisa didapatkan data periodik dan diketahui arah perkembangan stabilitas strukturnya.

Kata Kunci: stabilitas struktur; candi; pondasi; daya dukung

\begin{abstract}
Study of Mendut Temple Structure Stability is very important to evaluate the condition of the stability of the Mendut Temple building so that its sustainability will be maintained. Various activities carried out in the framework of this study included the analysis of monitoring data of the slope of the temple walls and the witdh of joint stone, archaeological
\end{abstract}


excavation in order to know the structure of the temple building, measuring the temple wall swelling, soil carrying capacity analysis, and old photo tracking.

The method used in this study is field observation, primary and secondary data collection, focus group discussion and data analysis. The results of the study show that based on the analysis data of measurement of the slope of the temple walls it was found that there was stones movement at the observation points of at most 4 seconds. Whereas during this twoyear period there was an increase in the with of the temple stone joint based on data crackmeter installed on the joint of stones. Based on excavation data it turns out that the structure of the temple foundation consists of only one layer of stone and there is a layer of mortar as a reinforcement of the foundation soil. Soil carrying capacity in the temple yard shows that the soil around the Mendut Temple is still good to support the temple building. The slope of the south east side wall is maximum $4 \mathrm{~mm}$ based on the measurement results using 3D Laser Scanner. Until now there has been no guidance on the slope of the walls in temple buildings, so guidelines need to be made so that it can be a comparison for subsequent measurements. The results of the search for old photographs of the Mendut Temple show that the first restoration consisted of several stages, no photos of the total restoration of the temple were found, and it turned out that in the structure of the temple there was a brick structure that had not been known so far.

To analyze the condition of structural stability, especially Mendut Temple, of course it cannot be implemented if it is only done with current data during year 2018, especially with the limitations of reference data about previous restoration. This 2018 data will be the baseline or basic data for future monitoring activities so that periodic data can be obtained and the development of structural stability is known.

Keywords: structural stability; temple; foundation; carrying capacity

\section{PENDAHULUAN}

Candi Mendut merupakan candi peninggalan agama Buddha yang terletak di Kelurahan Mendut, Kecamatan Mungkid, Kabupaten Magelang. Candi Mendut berada kurang lebih sebelah timur Candi Borobudur yang termasuk dalam warisan dunia bersama dengan Candi Borobudur dan Candi Pawon. Ketiga candi ini yaitu Borobudur, Pawon dan Mendut merupakan candi yang memiliki arti penting bagi umat Buddha khususnya, terutama untuk kegiatan ritual pada saat hari raya Waisak.

Candi Mendut bersama-sama dengan Candi Borobudur dan Candi Pawon beserta kawasannya merupakan kawasan cagar budaya tingkat nasional yang berpredikat sebagai warisan budaya dunia (World Heritage) yang ditetapkan oleh UNESCO sejak tahun 1991 dengan nama Borobudur Temple Compounds. Kawasan Cagar Budaya Borobudur ini ditetapkan menjadi kawasan cagar budaya peringkat nasional pada tahun 2014. Sebagai kawasan yang menjadi wisata unggulan yang diharapkan dapat mendatangkan banyak wisatawan baik dalam dan luar negeri, tinggalan arkeologi di dalamnya harus dipelihara dan dijaga dengan baik.

Pada saat ini pada Candi Mendut terdapat kerusakan yang harus segera ditangani supaya kerusakannya tidak berlanjut dan kelestariannya dapat terjaga. Berdasarkan hasil observasi dan monitoring yang telah dilakukan 
terdapat kerusakan batu yang ada di Candi Mendut diantaranya adalah kerusakan fisik seperti retak, pecah, pengelupasan batu, nat batu yang renggang, adanya kebocoran atap dan adanya indikasi penggelembungan. Untuk kerusakan kimiawi adalah adanya penggaraman yang tebal terutama di bagian bilik candi, sedangkan kerusakan biologi adalah tumbuhnya lumut dan alga di beberapa titik. Latar belakang kajian mengenai stabilitas struktur Candi Mendut ini adalah bahwa dengan adanya kerusakan yang terjadi di Candi Mendut akan berpengaruh terhadap stabilitas strukturnya atau tidak. Kajian ini sangat penting untuk dilakukan agar didapatkan hasil mengenai kondisi Candi Mendut saat ini sehingga dapat untuk melakukan tindakan konservasi yang diperlukan dan tidak membahayakan pengunjung.

Tidak seperti Candi

Borobudur yang memiliki dokumen yang lengkap mengenai pekerjaan konservasi dan pemugaran yang dilakukan, untuk Candi Mendut ini sangat terbatas data yang tersedia. Dokumen pemugaran yang dilakukan oleh Belanda tahun 1800-1900an tidak tersedia sehingga tidak diketahui dengan pasti pekerjaan apa saja yang dilakukan pada saat itu. Begitu pula tentang data-data mengenai pola susun dan sambungan batu serta denah/peta teknisnya. Dengan adanya berbagai kerusakan yang terdapat pada Candi Mendut maka kajian mengenai stabilitas struktur Candi Mendut sangat penting dilakukan untuk mengetahui kondisi terkini tentang stabilitas strukturnya.

Tujuan yang hendak dicapai dalam kajian ini adalah untuk mengetahui kondisi stabilitas struktur
Candi Mendut eksisting, sedangkan ruang lingkup kegiatan kajian dibatasi untuk kegiatan yang berhubungan dengan stabilitas struktur candi.

Tinjauan pustaka kajian ini disajikan hasil pengukuran kualitas batu dengan geombang ultrasonik. Pengukuran laju cepat rambat gelombang ultrasonik menggunakan alat berupa ultrasonic pulse velocity tester. Alat ini berfungsi untuk mengukur cepat rambat gelombang ultrasonik pada berbagai material salah satunya adalah batu andesit. Pengukuran ini diawali dengan memasang 2 kutub, yaitu pemancar dan penerima gelombang ultrasonik pada batu andesit. Gelombang yang dipancarkan dari pembangkitnya akan diterima oleh receiver kemudian dimunculkan dalam bentuk angka digital pada monitor dengan satuan $\mathrm{km} /$ det.

Pengukuran cepat rambat gelombang ultrasonik ini merupakan metode pengukuran non destruktif yang sangat membantu dalam melihat sifat kekuatan dari batu yang diukur. Selain itu dengan pengukuran ini dapat diketahui adanya retakan pada batuan. Pada dasarnya gelombang ultrasonik dapat merambat pada berbagai media, paling cepat merambat pada media padat. Pada media udara gelombang ultrasonik merambat paling lambat yaitu 330 $\mathrm{m} /$ det, pada media air $1,48 \mathrm{~km} / \mathrm{det}$ dan media air garam sedikit lebih besar yaitu $1,52 \mathrm{~km} /$ det. 

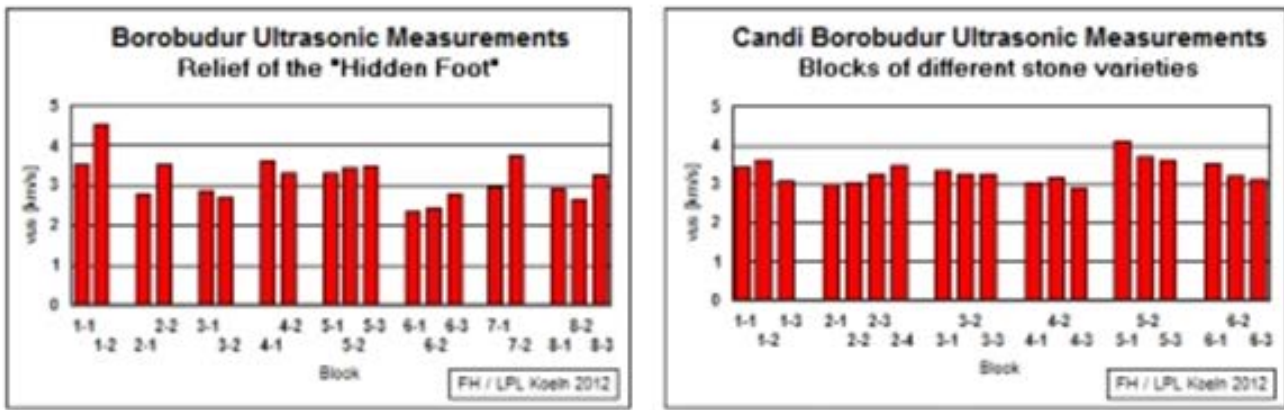

Gambar 1. Diagram cepat rambat gelombang ultrasonik di kaki (kiri) dan dinding (kanan) Candi Borobudur (Sumber: UNESCO, 2017)

Gambar 1 disajikan grafik hasil cepat rambat gelombang ultrasonik pada batu Candi Borobudur yang dilakukan pada tahun 2012.

Sampel batu yang diukur ada 2 lokasi yaitu blok-blok batu pada kaki candi (sekitar relief Karmawibhangga) dan pada susunan batu di bagian tenggara candi. Berdasarkan grafik di atas diketahui bahwa batu pada kaki candi memilki cepat rambat gelombang ultrasonik $2,2-4,4 \mathrm{~km} / \mathrm{det}$ dengan akumulasi nilai diantara 2,5$3,5 \mathrm{~km} /$ det. Sedangkan pada susunan batu di bagian tenggara Candi Borobudur (yang merupakan penutup dari relief Karmawibhangga) memiliki nilai kecepatan 3-4,2 km/det. Dari pengukuran tersebut dapat disimpulkan bahwa batu Candi Borobudur memiliki cepat rambat gelombang ultrasonik sebesar 2-4 $\mathrm{km} /$ det.

Pengukuran cepat rambat gelombang ultrasonik batu pada Candi Mendut dilakukan pada tahun 2017 dengan mengambil sampel blok-blok batu yang asli pada bagian dinding luar dan bilik candi. Gambar 2 adalah grafik hasil pengukurannya.

Dari grafik tersebut dapat diketahui bahwa batu bagian luar Candi Mendut memiliki kecepatan gelombang ultrasonik sebesar 2,5-3,5 $\mathrm{km} /$ det. Sedangkan pada batu bagian

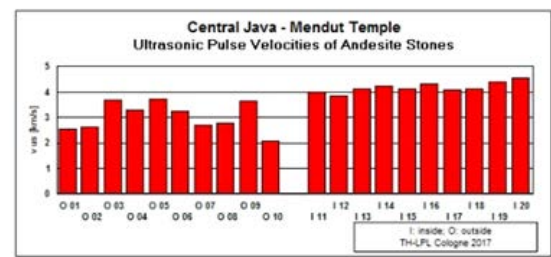

Gambar 2. Diagram cepat rambat gelombang ultrasonik pada batu luar dan batu bilik Candi Mendut (Sumber:

UNESCO, 2017)

dalam Candi Mendut yaitu bagian bilik candi memiliki kecepatan sekitar 4 $\mathrm{km} /$ det. Penyebab pebedaan nilai kecepatan gelombang ultrasonik pada batu luar dan dalam Candi Mendut dapat disebabkan karena:

1. Sifat dari batuan sendiri yang berbeda

2. Batu andesit bagian dalam candi memiliki kelembaban yang lebih tinggi

3. Kandungan garam pada pori baru akibat adanya penggaraman menyebabkan peningkatan kecepatan rambat gelombang.

Bagian dalam candi yang memiliki kelembaban yang tinggi menyebabkan pori batuan yang 


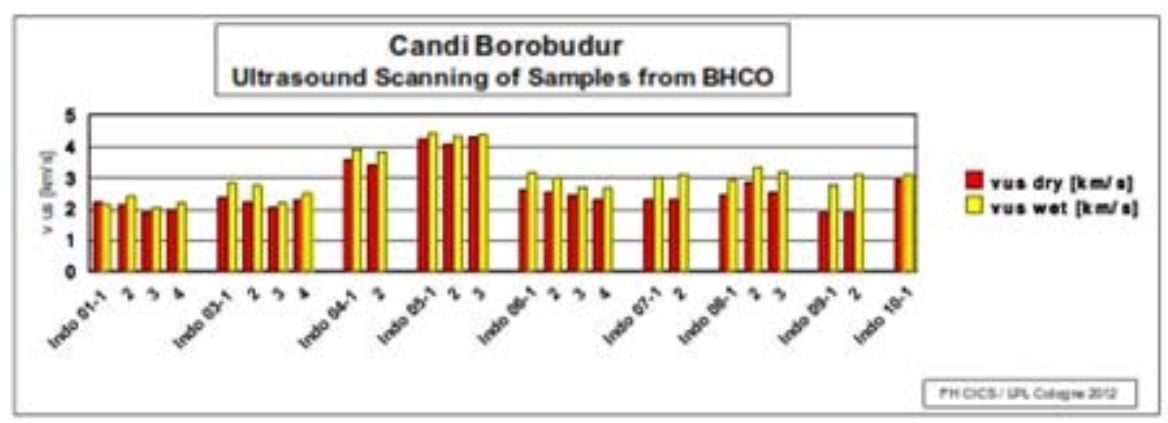

Gambar 3. Diagram cepat rambat gelombang ultrasonik sampel batu kering dan basah di Candi Borobudur (Sumber: UNESCO, 2017)

seharusnya terisi oleh udara akan terisi oleh adanya air sehingga hal ini dapat meningkatkan nilai kecepatan rambat gelombang ultrasonik dibandingkan dengan batu luar yang kering. Pada waktu-waktu sebelum ini telah dilakukan percobaan cepat rambat gelombang ultrasonik pada sampel batu Candi Borobudur yang berada dalam kondisi basah dan kering. Tujuan dari percobaan ini adalah untuk mengetahui perbadaan nilai kecepatan gelombang ultrasonik batu andesit yang basah dan kering (Gambar 3).

Dari grafik tersebut terlihat bahwa kelembaban yang tinggi pada sampel batu akan meningkatkan cepat rambat gelombang ultrasonik. Mayoritas sampel menunjukkan peningkatan 0,1-0,7 km/det. Apabila melihat kecepatan batu bagian dalam Candi Mendut sebesar $4 \mathrm{~km} / \mathrm{det}$ apabila dikurangi $0,7 \mathrm{~km} /$ det menjadi sekitar $3,3 \mathrm{~km} /$ det, sehingga nilainya sama dengan kecepatan pada batu luar Candi Mendut yaitu 2,5-3,5 km/det.

Kesimpulan yang dapat diambil dari hasil pengukuran ini adalah bahwa batu Candi Mendut memiliki rentang kecepatan rambat gelombang ultrasonik pada batu Candi Borobudur yaitu 2-4 km/det, sehingga kondisi batu Candi Mendut masih dalam kondisi bagus belum adanya indikasi penurunan kualitas batu.

Dari grafik di atas terlihat bahwa kelembaban yang tinggi pada sampel batu akan meningkatkan cepat rambat gelombang ultrasonik. Mayoritas sampel menunjukkan peningkatan 0,1-0,7 km/det. Apabila melihat kecepatan batu bagian dalam Candi Mendut sebesar $4 \mathrm{~km} / \mathrm{det}$ apabila dikurangi $0,7 \mathrm{~km} /$ det menjadi sekitar $3,3 \mathrm{~km} /$ det, sehingga nilanya sama dengan kecepatan pada batu luar Candi Mendut yaitu 2,5-3,5 km/det.

Kesimpulan yang dapat diambil dari hasil pengukuran ini adalah bahwa batu Candi Mendut memiliki rentang kecepatan rambat gelombang ultrasonik pada batu Candi Borobudur yaitu $2-4 \mathrm{~km} /$ det, sehingga kondisi batu Candi Mendut masih dalam kondisi bagus belum adanya indikasi penurunan kualitas batu.

\section{METODE}

Tahapan kegiatan kajian meliputi tiga tahap yaitu persiapan, pelaksanaan dan pelaporan. Tahap persiapan kegiatan kajian meliputi pembuatan proposal kegiatan dan rencana anggaran biaya, penelusuran referensi, konsultasi awal dengan narasumber dan mempersiapkan peralatan untuk pengambilan data 
lapangan. Tahap pelaksanaan kajian meliputi pengumpulan data lapangan, pengolahan data dan analisis. Sedangkan tahap terakhir adalah pembuatan laporan hasil kajian.

Dalam rangka mendukung kegiatan kajian stabilitas struktur Candi Mendut ini dilakukan pengumpulan data lapangan yang terdiri dari analisis hasil monitoring pengukuran kemiringan dinding Candi Mendut dan pengukuran nat batu menggunakan alat crackmeter, kegiatan ekskavasi (penggalian) arkeologi ini bertujuan untuk mencari infomasi mengenai struktur atau lapisan pondasi dari Candi Mendut, pengukuran kemiringan/pergerakan dari penggelembungan dinding, analisis jenis tanah di sekitar Candi Mendut dan kegiatan FGD (focus grup discussion) yang mengundang berbagai narasumber yang ahli di bidang struktur bangunan untuk mendapatkan masukan.

\section{HASIL DAN PEMBAHASAN}

\section{Analisis Hasil Monitoring}

Pengukuran Kemiringan Dinding Candi Mendut dan Pengukuran Nat Batu Menggunakan Alat Crackmeter Pengukuran kemiringan dinding pada Candi Mendut dilakukan pada bagian kaki dan tubuh candi dengan titik sampel pengukungan masing-masing 12 titik di tiap bagian. Pengukuran kemiringan dinding ini dilakukan mulai tahun 2014 sampai sekarang. Data kemiringan dinding bagian tubuh candi dimulai tahun 2014 namun karena tanda titik sampelnya hilang maka diperbaharui tandanya pada tahun 2015 sehingga data awal yang dipakai adalah tahun 2015. Untuk kemiringan dinding pada kaki candi dilakukan pengukuran mulai tahun 2014 .

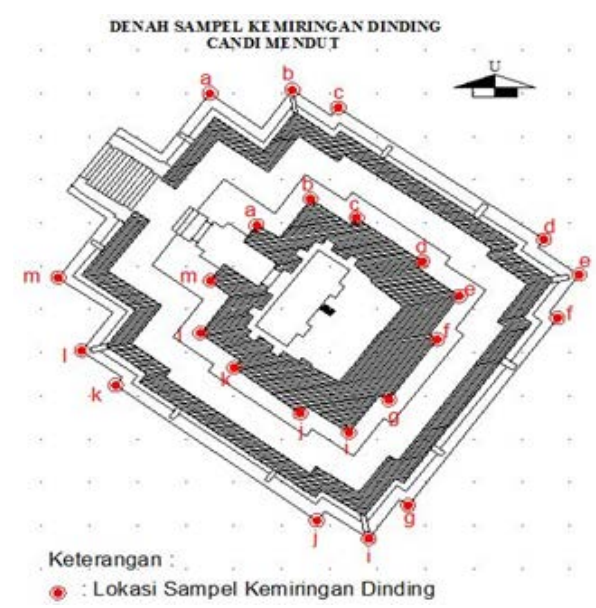

Gambar 4. Lokasi titik sampel pengukuran kemiringan kaki dan dinding Candi Mendut

Berikut ini akan disajikan grafik kemiringan dinding pada bagian kaki dan tubuh Candi Mendut tiap titik sampelnya dan arah kemiringannya. Grafik di bawah disajikan selisih kemiringan dinding untuk bagian kaki Candi Mendut arah sumbu X (arah barat laut-tenggara) dan sumbu Y (arah barat daya-timur laut). Dari grafik selisih kemiringan dinding pada bagian kaki Candi Mendut arah sumbu $\mathrm{X}$ yaitu arah barat laut-tenggara, terlihat bahwa hampir semua titik pengamatan mengalami pergerakan maksimal sebesar 4 detik. Selama periode 2014-2018 titik yang tidak mengalami perubahan dari posisi awal tahun 2014 adalah titik h, sedangkan titik pengamatan yang lain ada yang mengalami pergerakan ke arah tubuh candi kemudian kembali lagi ke posisi awal dan selanjutnya bergerak ke arah luar candi. 


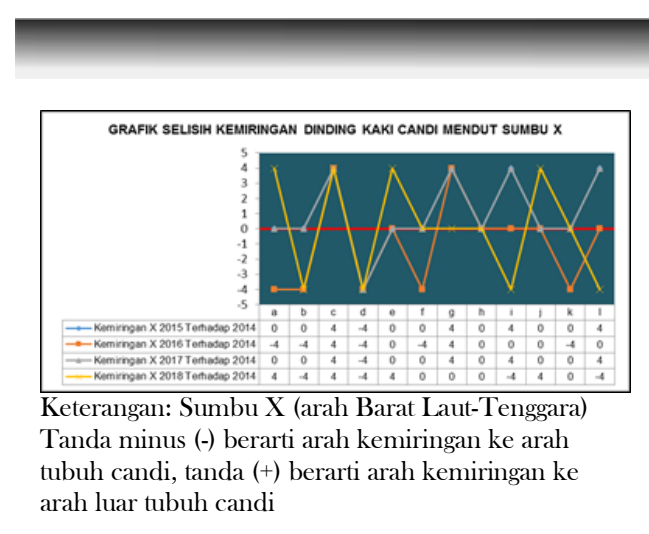

Gambar 5. Grafik selisih kemiringan dinding kaki Candi Mendut (2014-2018) sumbu X

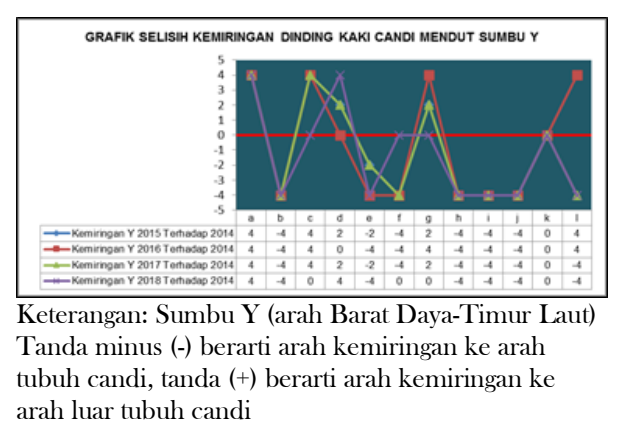

Gambar 6. Grafik selisih kemiringan dinding kaki Candi Mendut (2014-2018) sumbu Y

Dari grafik selisih kemiringan dinding pada bagian kaki Candi Mendut arah sumbu Y yaitu arah barat daya-timur laut tampak pada Gambar 6. Dari grafik terlihat bahwa hampir semua titik pengamatan mengalami pergerakan antara 2-4 detik. Selama periode 2014-2018 titik yang tidak mengalami perubahan dari posisi awal tahun 2014 adalah titik k, sedangkan titik pengamatan yang lain ada yang bergerak ke arah tubuh candi stabil yaitu titik b, h, i, dan j. titik yang bergerak ke arah luar candi dan stabil yaitu titik a.

Untuk kemiringan dinding Candi Mendut bagian tubuh tahun 2015-2018 disajikan pada grafik di Gambar 7 dan 8. Semua titik pengamatan mengalami pergerakan arah sumbu X (barat laut-tenggara).
Pergerakan dinding pada tubuh candi ada yang ke arah luar candi kemudian kembali keposisi semula dan ada yang bergerak ke arah sebaliknya. Begitu juga pergerakan ke arah sumbu Y. Secara garis besar di semua titik pengamatan mengalami pergerakan baik arah sumbu $\mathrm{X}$ ataupun sumbu $\mathrm{Y}$, namun gerakan tersebut seperti halnya batu yang bernafas. Titik-titik tersebut kadang bergerak ke arah luar candi dan ke dalam candi serta kembali lagi ke posisi semula.

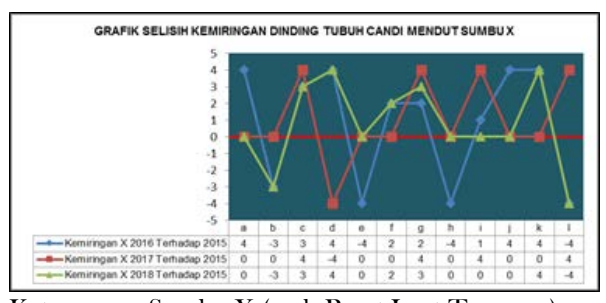

Keterangan: Sumbu X (arah Barat Laut-Tenggara) Tanda minus (-) berarti arah kemiringan ke arah tubuh candi, tanda $(+)$ berarti arah kemiringan kearah luar tubuh candi

Gambar 7. Grafik selisih kemiringan dinding tubuh Candi Mendut (2015-2018) sumbu X

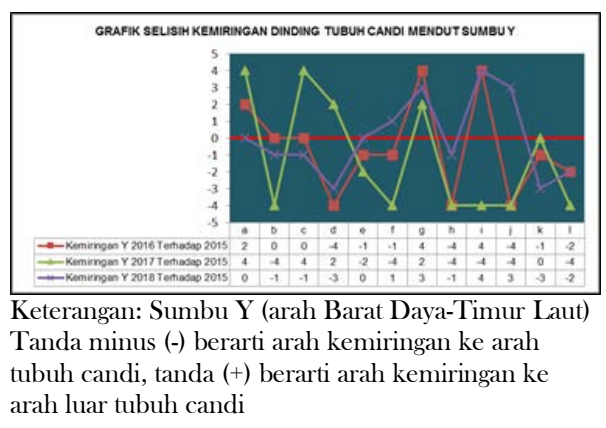

Gambar 8. Grafik selisih kemiringan dinding tubuh Candi Mendut (2015-2018) sumbu Y

Hasil pengukuran tahun 2015-2018 ini bahwa kondisi titik-titik pengukuran kemiringan dinding masih dalam kondisi yang aman dan stabil tidak melampaui batas yang ditentukan. Pedoman kemiringan dinding mengacu pada Guidelines for 
Damages Inspection and Evaluation International Institute of Seismology and Earthquake Engineering, Ministry of Construction, Japan dengan klasifikasi sebagai berikut:

$$
\begin{aligned}
& \square \text { Ringan }: \Theta<3,6^{\circ} \\
& 4 \text { Sedang : } 3,6^{\circ}<\theta<10,8^{\circ} \\
& \square \text { Berat : } 10,8^{\circ}<\theta<21,6^{\circ} \\
& \square \text { Terguling : } \Theta>21,6^{\circ}
\end{aligned}
$$

Hasil pengukuran kemiringan dinding untuk Candi Mendut menunjukkan bahwa kemiringan dinding Candi Mendut sangat kecil yaitu antara $0^{\circ}$ sampai $1^{\circ}$. Sedangkan selisih atau beda nilai kemiringan dinding antara pengukuran tahun 2015-2018, menunjukkan selisih antara $0-4$ menit atau paling besar $0,066^{\circ}$. Nilai ini sangat kecil sehingga dapat disimpulkan antara tahun 20152018 tidak ada perubahan kemiringan dinding Candi Mendut yang terjadi.

Langkah kedepan perlu dilakukannya pembuatan standar kemiringan dinding untuk Candi Mendut dengan cara melakukan pengukuran selama dalam periode tertentu kemudian dirata-rata. Nilai tersebut bisa dijadikan pedoman kemiringan dinding dan akan dibandingkan dengan waktu-waktu selanjutnya.

Dalam rangka memantau kerenggangan nat antar batu di Candi Mendut maka dipasang alat yang disebut crackmeter. Pada tahun 2015 dipasang dua buah alat crackmeter di bagian barat laut dan timur laut Candi Mendut dan tahun 2017 dipasang alat pada bagian tenggara dan bilik candi. Pengumpulan data crackmeter ini tampak seperti pada Tabel 1. Data logger dari alat crackmeter nomor 1 dan 2 pada tahun 2017 rusak karena terkena air sehingga sampai dengan saat ini crackmeter yang masih berfungsi adalah nomor 3 dan 4 (BKB, 2017).

Berdasarkan Tabel 1 dapat terlihat bahwa nat yang dipantau memiliki kecenderungan yang semakin renggang. Sebagai contoh untuk crackmeter nomor 2 (timur laut candi) selama tahun 2015-2016 terdapat penambahan kerenggangan nat sebesar $0,236 \mathrm{~mm}+0,088 \mathrm{~mm}=$ 0,32 mm. Begitu juga dengan crackmeter nomor 3 dan 4. Crackmeter nomor 3 (tenggara candi) selama tahun 2017-2018 terdapat penambahan kerenggangan nat sebesar 0,12 $\mathrm{mm}$ dan crackmeter nomor 4 (bilik candi) terjadi penambahan kerenggangan nat sebesar $0,11 \mathrm{~mm}$. walaupun nilai penambahan kerenggangan nat batu ini dalam kisaran sepersepuluh $\mathrm{mm}$, perlu diwaspadai dan dipantau secara terus menerus karena di semua tempat memberikan indikasi kerenggangan nat yang semakin besar.

Kedepan perlu pengamatan yang kontinyu terhadap titik sampel yang diukur kerenggangan nat menggunakan alat crackmeter sehingga dapat diamati apakah semakin hari semakin renggang. Sementara ini data yang tersedia baru selama 2 tahun terakhir. Berikut disajikan grafik crackmeter Candi Mendut untuk data logger 3 dan 4 tahun 2017-2018 (Gambar 9 dan 10). Dari kedua grafik di bawah terlihat garis trennya selalu naik, artinya pada titik pengamatan 3 dan 4 memiliki kecenderungan nat batu yang semakin merenggang selama dua tahun ini (2017-2018). 
Tabel 1. Hasil monitoring crackmeter di Candi Mendut

\begin{tabular}{|c|c|c|c|c|}
\hline $\begin{array}{l}\text { Data } \\
\text { logger }\end{array}$ & 2015 & 2016 & 2017 & 2018 \\
\hline $\begin{array}{l}\text { Data } \\
\text { logger } 1\end{array}$ & $\begin{array}{l}\text { Terjadi penambahan } \\
\text { retakan sebesar: } \\
=3570-3520 \text { digit } \\
=50 \text { digit } \times 0,001181 \\
\mathrm{~mm} / \text { digit } \\
=0,059 \mathrm{~mm}\end{array}$ & $\begin{array}{l}\text { tidak terjadi } \\
\text { perubahan }\end{array}$ & Sensor rusak & Sensor rusak \\
\hline $\begin{array}{l}\text { Data } \\
\text { logger } 2\end{array}$ & $\begin{array}{l}\text { Terjadi penambahan } \\
\text { retakan sebesar: } \\
=3450-3250 \text { digit } \\
=200 \text { digit } \mathrm{x} \\
0,001181 \mathrm{~mm} / \text { digit } \\
=0,236 \mathrm{~mm}\end{array}$ & $\begin{array}{l}\text { Terjadi } \\
\text { penambahan } \\
\text { retakan sebesar: } \\
=3250-3175 \text { digit } \\
=75 \text { digit } \mathrm{x} \\
0,001181 \mathrm{~mm} / \text { digit } \\
=0,088 \mathrm{~mm}\end{array}$ & Sensor rusak & Sensor rusak \\
\hline $\begin{array}{l}\text { Data } \\
\text { logger } 3\end{array}$ & $\begin{array}{l}\text { Sensor belum } \\
\text { terpasang }\end{array}$ & $\begin{array}{l}\text { Sensor belum } \\
\text { terpasang }\end{array}$ & $\begin{array}{l}\text { Terjadi } \\
\text { penambahan } \\
\text { retakan sebesar: } \\
=3740-3661 \text { digit } \\
=79 \text { digit } \mathrm{x} \\
0,001181 \mathrm{~mm} / \text { digit } \\
=0,093 \mathrm{~mm}\end{array}$ & $\begin{array}{l}\text { Terjadi } \\
\text { penambahan } \\
\text { retakan sebesar: } \\
=3661-3639 \\
\text { digit } \\
=22 \text { digit } \mathrm{x} \\
0,001181 \\
\mathrm{~mm} / \text { digit } \\
=0,026 \mathrm{~mm}\end{array}$ \\
\hline $\begin{array}{l}\text { Data } \\
\text { logger } 4\end{array}$ & $\begin{array}{l}\text { Sensor belum } \\
\text { terpasang }\end{array}$ & $\begin{array}{l}\text { Sensor belum } \\
\text { terpasang }\end{array}$ & $\begin{array}{l}\text { Terjadi } \\
\text { penambahan } \\
\text { retakan sebesar: } \\
=3765-3706 \text { digit } \\
=59 \text { digit } \mathrm{x} \\
0,001181 \mathrm{~mm} / \text { digit } \\
=0,069 \mathrm{~mm}\end{array}$ & $\begin{array}{l}\text { Terjadi } \\
\text { penambahan } \\
\text { retakan sebesar: } \\
=3706-3671 \\
\text { digit } \\
=35 \text { digit x } \\
0,001181 \\
\mathrm{~mm} / \text { digit } \\
=0,041 \mathrm{~mm}\end{array}$ \\
\hline
\end{tabular}

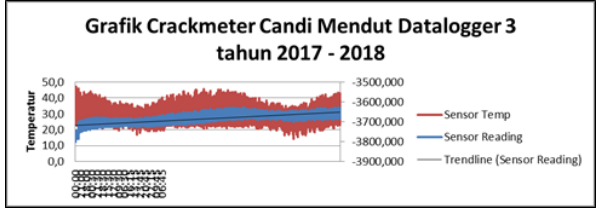

Gambar 9. Grafik crackmeter Candi Mendut data logger 3 tahun 2017-2018

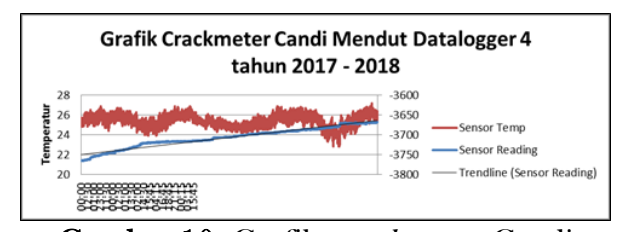

Gambar 10. Grafik crackmeter Candi Mendut data logger 4 tahun 2017-2018

Untuk data logger 3 selama tahun 2017-2018 mengalami penambahan kerenggangan nat sebesar 0,12 mm, sedangkan untuk data logger 4 mengalami penambahan kerenggangan nat sebesar $0,11 \mathrm{~mm}$. Untuk tahun-tahun selanjutnya perlu dipantau/dimonitor secara intensif titik-titik yang diperkirakan rawan terjadi kerenggangan nat sehingga kita bisa melakukan tindakan yang diperlukan.

\section{Ekskavasi untuk Mengetahui Pondasi Candi}

Kegiatan ekskavasi ini bertujuan untuk mengetahui stabilitas struktur Candi Mendut dengan 
mengumpulkan data-data lapangan dari hasil ekskavasi dengan metode arkeologi. Dari hasil ekskavasi diketahui lapisan batu pada kaki Candi Mendut. Kegiatan ekskavasi sementara ini telah selesai dilakukan dengan membuka 2 buah kotak gali untuk mengetahui struktur pondasi Candi Mendut.

Kegiatan ekskavasi ini dilakukan selama lima hari tanggal 26 Juni-3 Juli 2018. Lokasi ekskavasi terletak di Situs Candi Mendut, Dusun/Lingkungan Mendut 2, Kelurahan Mendut, Kecamatan Mungkid, Kabupaten Magelang, Provinsi Jawa Tengah. Kotak yang diekskavasi adalah kotak yang terletak pada Grid A dan Grid B. Pada Grid B, kotak yang telah digali adalah kotak B1.XX dan pada Grid A, kotak yang digali yaitu kotak A1.V dan A2.XXV. Pemilihan lokasi kotak gali ini dengan mempertimbangkan bahwa kotak gali tersebut akan memberikan informasi/gambaran mengenai struktur pondasi Candi Mendut. Setiap kotak yang digali, dilakukan sistem spit dengan interval $20 \mathrm{~cm}$. Pada waktu sebelumnya sekitar tahun 2014 di area Candi Mendut dan halaman telah dibuat grid alam rangka panduan pelaksanaan ekskavasi/penggalian. Grid yang dipakai mengacu pada grid yang telah dibuat sebelumnya. Berikut ini ditampilkan grid Candi Mendut dan lokasi ekskavasi dalam rangka melihat struktur pondasi Candi Mendut (Gambar 11).

Kotak gali B1.XX berukuran 2x2 m terletak pada sisi timur laut candi. Kotak digali pada kedalaman 1 meter dengan interval spit $20 \mathrm{~cm}$. Terdapat akar pohon dewata dengan diameter $\pm 5 \mathrm{~cm}$ dan panjang 1 meter mengarah ke utara. Pada spit 2 sisi
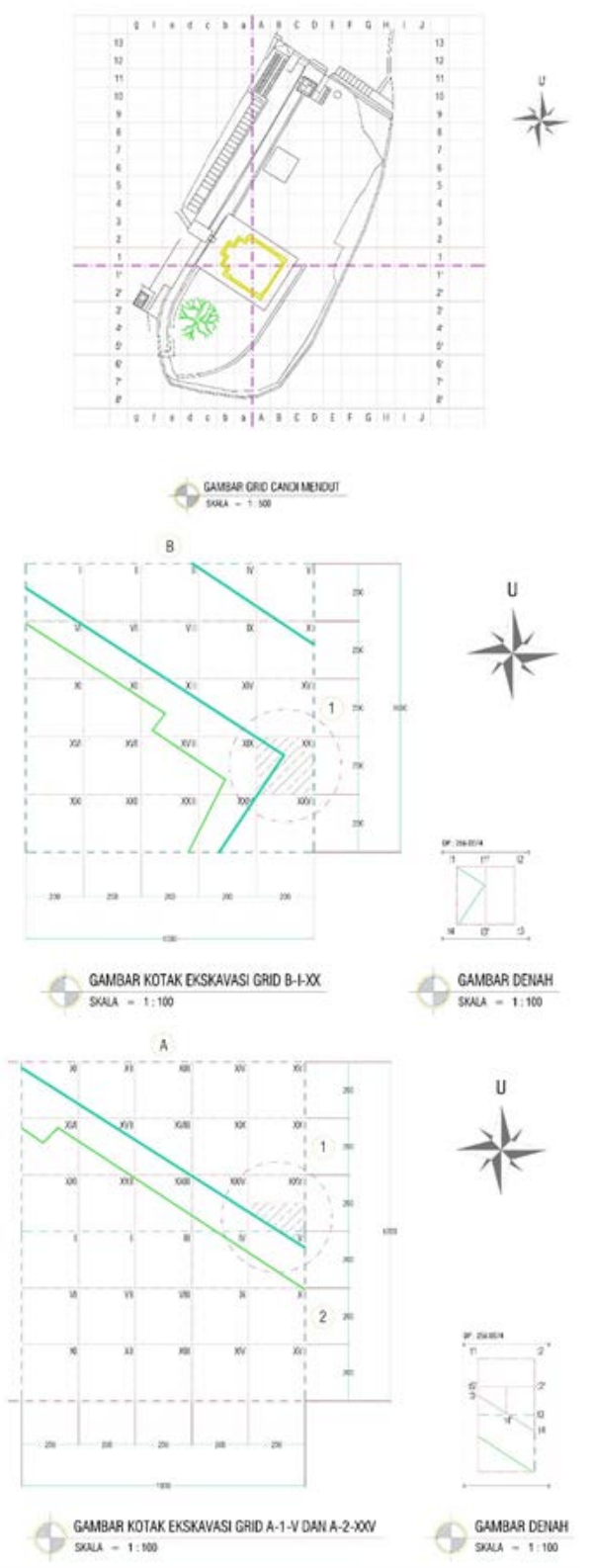

Gambar 11. Gambar grid kotak gali ekskavasi

timur ditemukan batu andesit berukuran $\pm 80 \times 40 \mathrm{~cm}$ pada sudut $\mathrm{t} 3$ juga terdapat akar $\pm 25 \mathrm{~cm}$ mengarah ke timur laut. Pohon dewata terdapat di barat daya Candi Mendut, berseberangan dengan lokasi kotak B1.XX. Artinya, kemungkinan akar menembus tanah bawah candi atau menjalar sepanjang tepi tenggara candi. 


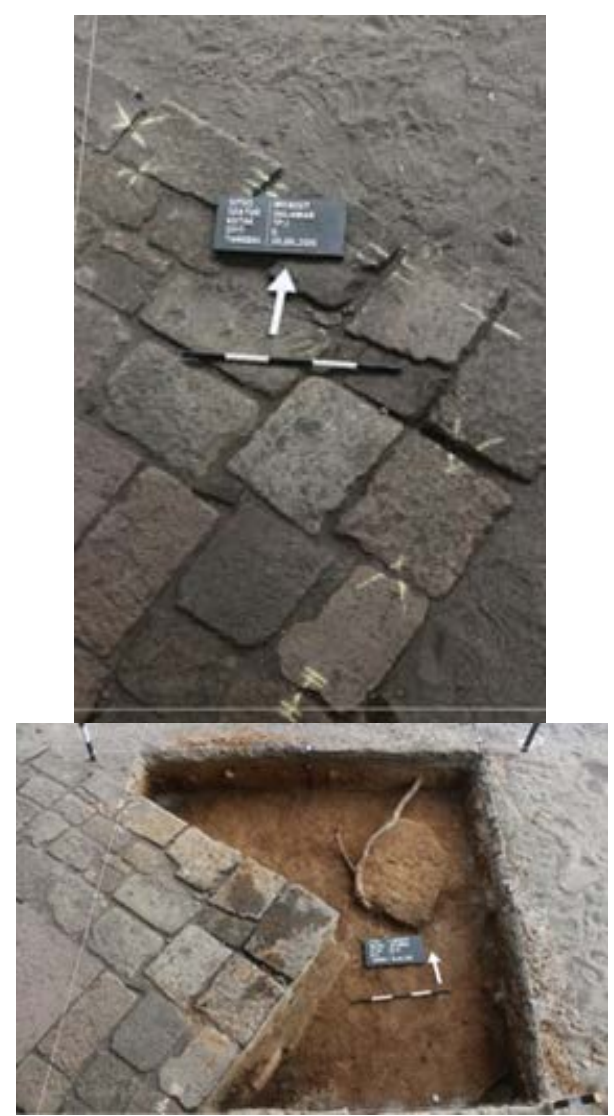

Gambar 12. Foto atas tampak kotak B1.XX spit 0, Foto bawah tampak kotak gali B1.XX spit 2

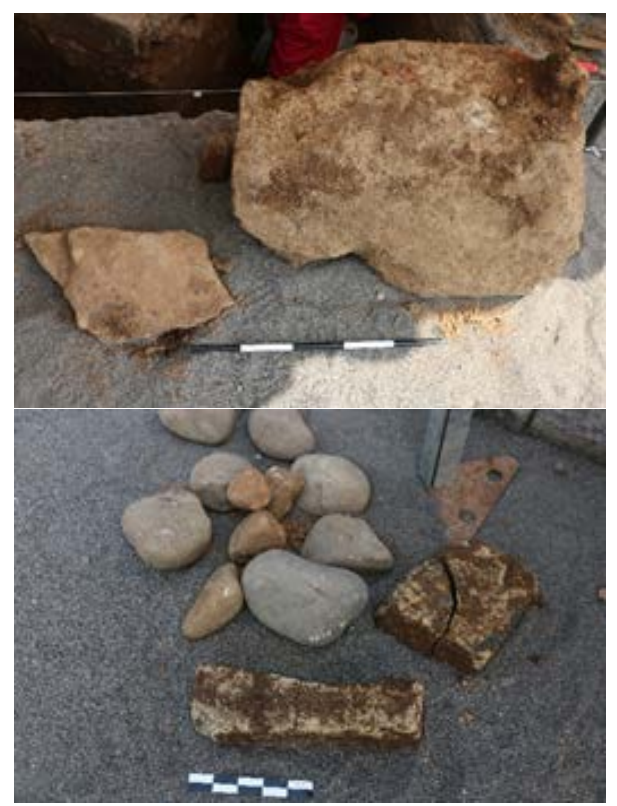

Gambar 13. Temuan pada kotak gali B1.XX
Untuk hasil temuan selama proses ekskavasi/penggalian di kotak gali B1.XX adalah adanya temuan batu lepas, bata dan batu putih tampak seperti pada foto di bawah. Temuan batu candi berupa batu isian dan pecahan batu seperti tampak pada gambar bawah kanan. Selain itu ada temuan beberapa blok batu putih dan batu kali/batu gundul di dalam kotak gali. Benda-benda temuan tersebut semuanya merupakan temuan lepas yang yang berfungsi sebagai urug.

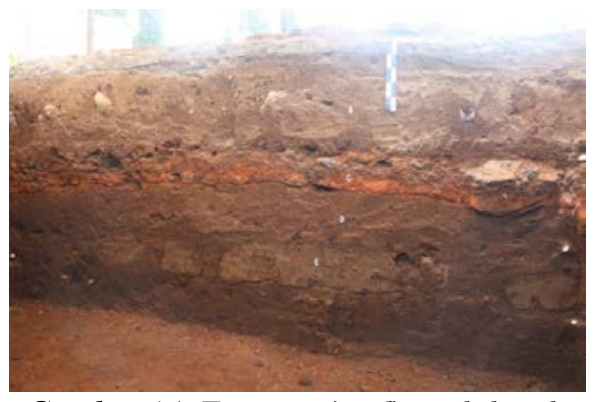

Gambar 14. Foto stratigrafi tanah kotak B1.XX dinding utara

Pada kotak gali pertama B1.XX dinding sebelah utara, terdapat stratigrafi tanah yang terdiri dari beberapa lapis dari yang paling atas yaitu lapisan pudel, abu merapi, pasir urug dan kerikil, pasir dan kerikil kasar, urugan tanah, bubukan bata, urugan tanah dan lempung, dan urugan tanah. Lapis kedelapan yang berupa urugan tanah dan lempung terlihat bahwa sebarannya hanya pada tempat-tempat tertentu dan tidak merata. Untuk mengetahui lapisan ini memiliki perbedaan atau tidak dengan lapisan di atas dan bawahnya dilakukan analisis ukuran butirnya.

Tiap lapisan tanah diambil sampelnya dan dianalisis fisik untuk mengetahui ukuran butirannya. Tabel 2 adalah hasil analisis ukuran butir dari tiap lapisan tanah. Analisa butir ini dilakukan dengan tujuan untuk 
Tabel 2. Analisa ukuran butir sampel tanah Candi Mendut

\begin{tabular}{|c|c|c|c|c|c|c|c|c|c|c|c|c|}
\hline No. & Kode sampel & Nama Lapisan & $\begin{array}{c}\text { Massa sampel } \\
\text { (gr) }\end{array}$ & $<0.045$ & $0.045-0.063$ & $0.063-0.125$ & $0.125-0.250$ & $0.250-0.500$ & $0.500-1.00$ & $1.00-2.00$ & $2.00-4.00$ & $>4.00$ \\
\hline 1 & L1 B1XX & Pudel & 100 & 1,2 & 3,1 & 9,6 & 18,2 & 24,1 & 21,2 & 13,8 & 4,9 & 3,9 \\
\hline 2 & L2 B1XX & Abu merapi & 15 & 0,1 & 0,3 & 5,0 & 5,6 & 4,0 & - & - & - & - \\
\hline 3 & L3 B1XX & Pasir urug+kerikil & 50 & 0,6 & 0,6 & 7,4 & 9,1 & 10,3 & 8,7 & 4,7 & 2,8 & 5,8 \\
\hline 4 & L4 B1XX & Pasir+kerikil kasar & 50 & 0,7 & 0,7 & 3,0 & 6,5 & 7,5 & 7,8 & 6,1 & 5,2 & 12,5 \\
\hline 5 & L5 B1XX & Urugan tanah & 50 & 0,2 & 0,6 & 7,2 & 8,4 & 11,6 & 15,0 & 6,5 & 0,5 & - \\
\hline 6 & L6 B1XX & Bubukan bata & 50 & 0,4 & 0,5 & 10,0 & 7,6 & 9,5 & 10,0 & 8,3 & 3,7 & - \\
\hline 7 & L7 B1XX & Urugan Tanah & 50 & 0,1 & 1,1 & 6,7 & 8,1 & 11,8 & 14,4 & 6,8 & 0,8 & 0,2 \\
\hline 8 & L8 B1XX & Urugan Tanah+lempung & 50 & - & 1,0 & 7,3 & 12,7 & 18,6 & 9,6 & 0,8 & - & - \\
\hline 9 & L9 B1XX & Urugan Tanah & 50 & 0,2 & 0,6 & 5,7 & 8,2 & 12,9 & 15,1 & 6,9 & 0,3 & 0,1 \\
\hline
\end{tabular}

mengetahui perbedaan antar lapisan tanah yang ada pada kotak hasil ekskavasi Candi Mendut.

Dari Tabel 2 terlihat distribusi ukuran butir pada tiap lapisan tanah yang terdapat pada kotak gali B1.XX. Penentuan ukuran butir pasir didasarkan pada skala Wentworth. Nama skala Wentworth digunakan untuk klasifikasi materi partikel agregate. Skala ini dipilih karena pembagian menampilkan percerminan distribusi alami partikel sedimen. Empat pembagian dasar yang dikenal adalah lempung $(<4 \mu \mathrm{m})$, lanau $(4 \mu \mathrm{m}-63 \mu \mathrm{m})$, pasir $(63 \mu \mathrm{m}-2$ $\mathrm{mm})$ dan kerikil/agregat $(>2 \mathrm{~mm})$ (https://www.scribd.com/doc/ 266777752/Klasifikasi-Skala-

Tabel 3. Nama partikel berdasar ukuran butir

\begin{tabular}{|c|c|c|}
\hline \multicolumn{2}{|r|}{ NAMA PARTIKEL } & $\begin{array}{l}\text { DIAMETER PARTIKEL } \\
\text { (mm) }\end{array}$ \\
\hline \multirow{4}{*}{$\begin{array}{l}\text { Kerikil } \\
\text { (gravol) }\end{array}$} & Boulders & $>256$ \\
\hline & Cobbles (bongkah) & $64-256$ \\
\hline & Pebbles (kerikil) & $4-64$ \\
\hline & Granules (butir) & $2-4$ \\
\hline \multirow{5}{*}{ Pasir $(\tan d)$} & Very coarse sand (sangat kasar) & $1-2$ \\
\hline & Coarse sand (kasar) & $0,5-1$ \\
\hline & Medium sand (sedang) & $0,25-0,5$ \\
\hline & Fine sand (halus) & $0,125-0,25$ \\
\hline & Very fore sand' (sangat halus) & $0,0625-0,125$ \\
\hline \multicolumn{2}{|l|}{ Lanau (silt) } & $0,004-0,0625(1 / 256-1 / 16)$ \\
\hline \multicolumn{2}{|c|}{ Lempung (clay) } & $<0,004(<1 / 256)$ \\
\hline
\end{tabular}

Tabel 4. Nama partikel tiap lapisan tanah

\begin{tabular}{clc}
\hline No. & \multicolumn{1}{c}{ Lama Lapisan } & Nama Partikel \\
\hline 1 & Pudel & Pasir medium \\
\hline 2 & Abu merapi & Pasir halus hingga sangat halus \\
\hline 3 & Pasir urug+kerikil & Pasir sedang hingga halus \\
\hline 4 & Pasir+kerikil kasar & Pasir kasar hingga sedang \\
\hline 5 & Urugan tanah & Pasir kasar \\
\hline 6 & Bubukan bata & - \\
\hline 7 & Urugan Tanah & Pasir kasar \\
\hline 8 & Urugan Tanah+lempung & Pasir sedang hingga halus \\
\hline 9 & Urugan Tanah & Pasir kasar \\
\hline
\end{tabular}


Wentworth). Untuk lebih lengkapnya terlihat dari Tabel 3 dan 4.

Dari Tabel 3 dan 4 dapat disimpulkan bahwa lapisan tanah dalam stratigrafi tanah di kotak gali B1.XX terdapat 9 lapis tanah yang memiliki ukuran butir yang berbeda. Pada tiap sisi kotak gali terdapat lapisan bata yang ditumbuk dan diurug untuk pondasi bangunan. Lapisan bubukan bata tersebut berada pada kedalaman kurang lebih $50 \mathrm{~cm}$ dari atas dengan ketebalan $5-10 \mathrm{~cm}$.

Pada fondasi Candi Induk Sewu juga terdapat bubukan bata yang disebarkan/diurug pada tanah pondasi di bawah bangunan candi. Adanya bubukan bata yang disebarkan di sekitar tanah pondasi candi ini mungkin berhubungan dengan aspek simbolis konsep keagamaan saat itu bahwa pemilihan bata adalah sebagai asas kosmis yang menjadi asal muasal segala sesuatu yang bersifat kebendaan dan candi yang dibuat dengan cara ini telah memenuhi syarat sebagai tempat bersemayamnya purusa (dewa) yaitu asas kejiwaan alam semesta.

Kondisi tanah spit 1, terdiri dari lapisan pudel, abu dan tanah yang teksturnya keras/tidak gembur. Kondisi tanah kering. Terdapat 2 buah batu kali berukuran diameter $\pm 10 \mathrm{~cm}$ dan fragmen bata yang juga berukuran hampir sama. Pada spit 1 sudah terlihat adanya batu andesit setebal 14 $\mathrm{cm}$.

Kotak gali selanjutnya adalah A1.V. Alasan penggalian kotak A1.V adalah karena pada area ini tidak terdapat batu tambahan (yang dilakukan oleh BPCB Jawa tengah) pada permukaan tanah yang akan digali. Tujuan pembukaan kotak ini adalah untuk memastikan atau mencari data lapisan batu yang berasal dari susunan batu asli Candi Mendut.
Kotak gali A1.V berada di sisi timur laut Candi Mendut (tepat pada

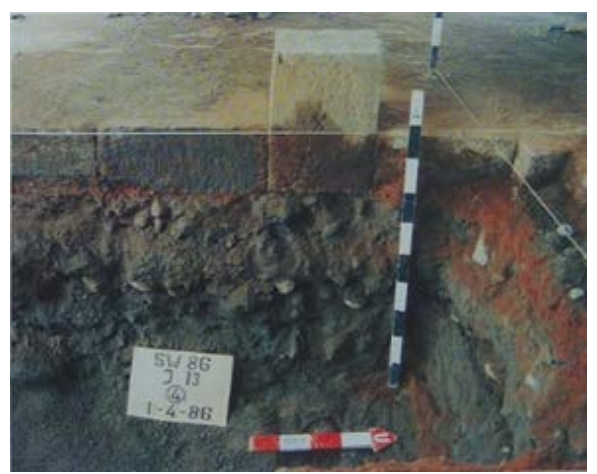

Gambar 15. Bubukan bata pada pondasi Candi Induk Sewu

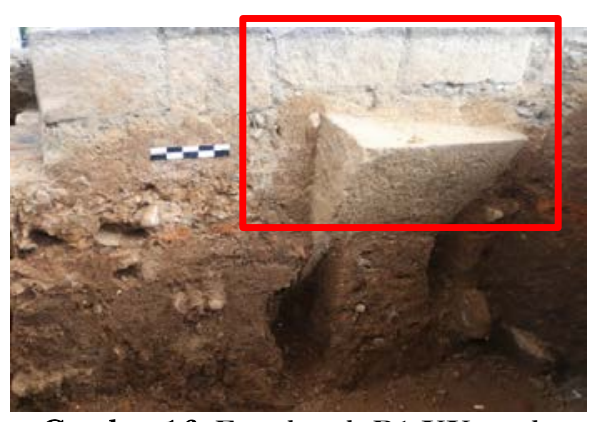

Gambar 16. Foto kotak B1.XX pada dinding menghadap timur laut, spit 2 terlihat adanya batu andesit

kaki candi/menempel pada struktur candi). Sebagaimana kita ketahui, bahwa pintu masuk Candi Mendut berada di barat laut. Kotak A1.V berukuran 2 × 2 meter. Karena pada kotak A1.V ditemukan struktur batu, maka dilakukan pelebaran ke arah utara (kotak A2.XXV). Pada kotak gali

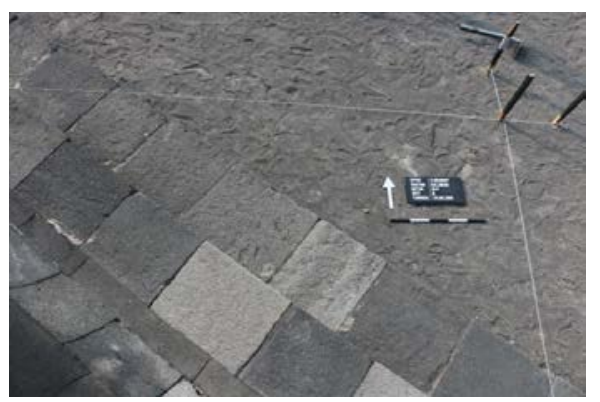

Gambar 17. . Foto tampak atas kotak A1.V spit 0 
A1.V, struktur pada sisi timur lebih rapat, mempunyai 3 lapis batu mendatar. Batu-batu ini merupakan batu isian. Setelah membuka kotak A1.V ternyata tidak bisa dilanjutkan kalau tidak membuka kotak di sebelah utaranya karena sudah tidak ada ruang lagi untuk digali. Setelah membuka kotak gali di sebelah utaranya yaitu kotak A2.XXV dengan ukutan 2x1 m maka penggalian bisa dilanjutkan kembali.

Pada spit 1 ini lapisan tanahnya terdiri beberapa lapisan yaitu lapisan pudel, lapisan abu merapi, lapisan pasir urug dan kerikil halus dan lapisan pasir dan kerikil kasar. Temuan yang ada di spit 1 ini adalah temuan batu lepas berupa batu isian yang ditata, sebagian memiliki ikatan/nat yang yang rekat sebagian lagi tidak. Temuan batu yang rekatannya kuat tidak dibongkar sedangkan batu yang tidak rekat bisa dibongkar.

Pada spit 3 setelah susunan batu isian dibongkar terlihat bahwa susunan batu pondasi yang hanya satu lapis batu yang terlihat di permukaan setebal $20 \mathrm{~cm}$. Di bawah lapisan batu terdapat lapisan mortar/plester yang bercampur dengan batu gundul/kerakal setebal kurang lebih 20

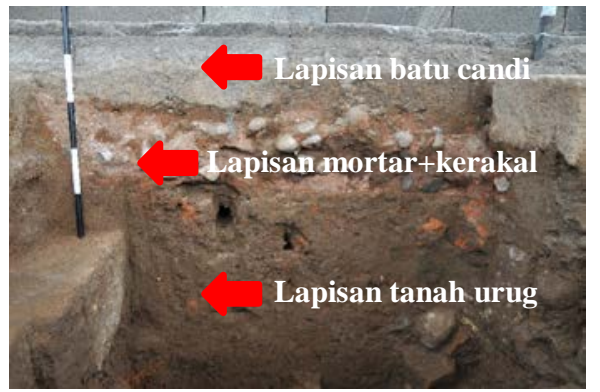

Gambar 18. Struktur pondasi pada bagian tepi Candi Mendut sisi timur laut

$\mathrm{cm}$, setelah itu di bawahnya adalah tanah urug. Lapisan mortar yang ada di bawah batu candi diprediksi adalah hasil pekerjaan pemugaran pertama oleh Belanda, karena pada waktu pembangunan candi belum dikenal adanya mortar. Apabila ini benar berarti pemerintah Belanda pada saat itu membongkar sampai bagian kaki candi dan memperbaiki bagian tanah pondasi untuk memperkuat struktur. Lapisan mortar ini diketahui pada bagian tepi candi dimana dilakukan ekskavasi, belum diketahui apakah lapisan mortar ini juga sampai ke dalam di bawah struktur penopang tubuh candi. Apabila Candi Mendut ini tidak dipugar total pada waktu pemugaran pertama oleh Belanda maka perbaikan/pemugaran

Tabel 5. Hasil analisis mortar pondasi Candi Mendut

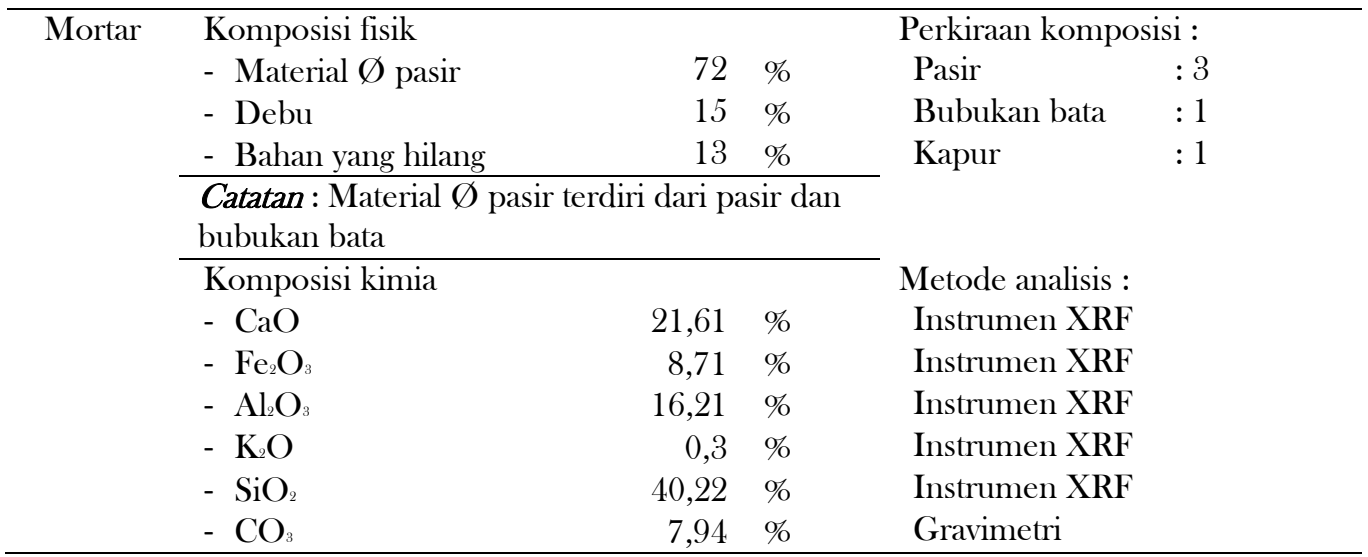




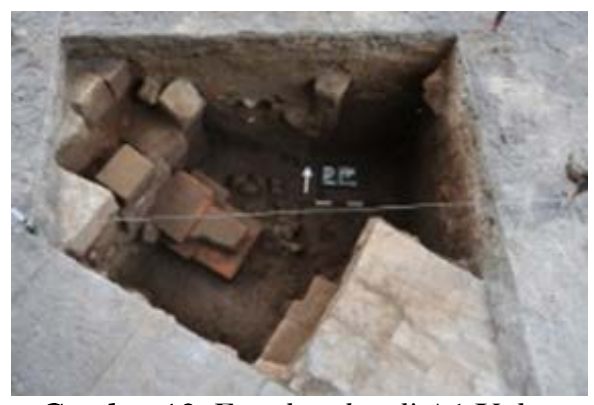

Gambar 19. Foto kotak gali A1.V dan A2.XXV spit 5

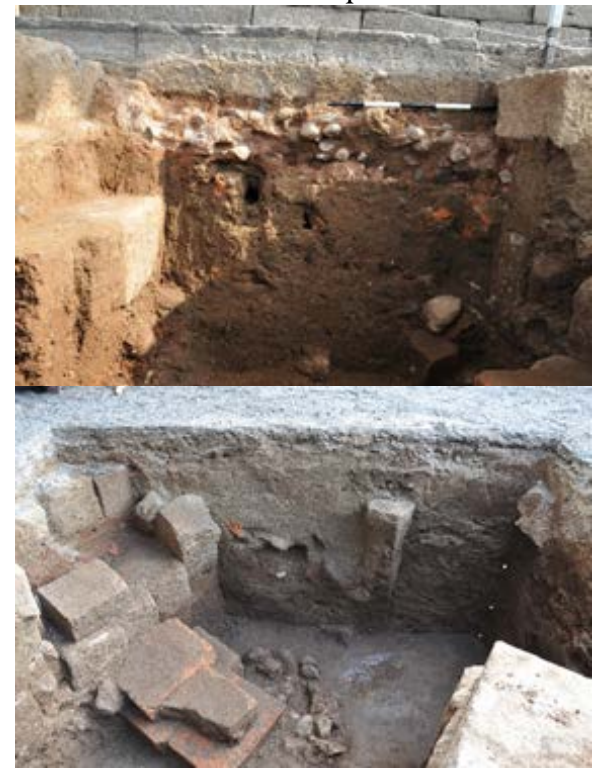

Gambar 20 dan 21. Foto (atas) stratigrafi tanah di bawah batu Candi Mendut

bagian tepi, (bawah) stratigrafi tanah pada kotak gali A2.XXV sisi utara

dilakukan secara parsial pada tempattempat yang mengalami kerusakan.

Lapisan mortar ini diambil sampelnya untuk di analisis secara fisik komposisinya di Laboratorium Balai Konservasi Borobudur dan didapatkan hasil pada Tabel 5 .

Dari Tabel 5 dapat diketahui komposisi mortar pada bagian pondasi adalah pasir, bubukan bata dan kapur dengan perbandingan $3: 1$ : 1. Pada kajian terdahulu juga diketahui bahwa pada atap Candi Mendut juga terdapat mortar hasil pemugaran oleh pemerintah Belanda. Ada perbedaan perbandingan komposisi dengan mortar yang ada di tanah pondasi, yaitu mortar pada atap candi terdiri dari pasir, bubukan bata, kapur dengan perbandingan $2: 1: 1$.

Pada spit 4 dan 5 terdapat temuan 4 blok bata yang disusun namun tidak menyambung dengan sekitarnya. Selain itu terdapat batu kerakal yang sepertinya berfungsi sebagai urug. Di beberapa tempat terdapat sebaran bubukan bata di tanah ada kedalaman sekitar $60 \mathrm{~cm}$, dan tersebar tidak merata

Stratigrafi tanah pada tepi Candi Mendut pada kotak gali A1.V terdiri dari lapisan batu candi setebal $20 \mathrm{~cm}$, lapisan mortar dan kerakal kurang lebuh setelah $20 \mathrm{~cm}$, dan tanah urug. Pada beberapa tempat terdapat sebaran bubukan bata yang tidak merata. Pada kotak gali A2.XXV sisi utara stratigrafi tanah terdiri dari lapisan pudel, lapisan abu merapi, pasir urug+kerikil halus, pasir+kerikil kasar dan tanah urug. Pada kedalaman kunga lebih $60 \mathrm{~cm}$ terdapat sebaran bubukan bata yang tidak merata. Di bawah ini disajikan gambar hasil digitalisasi stratigrafi tanah pada kotak gali A1.V dan A2.XXV.

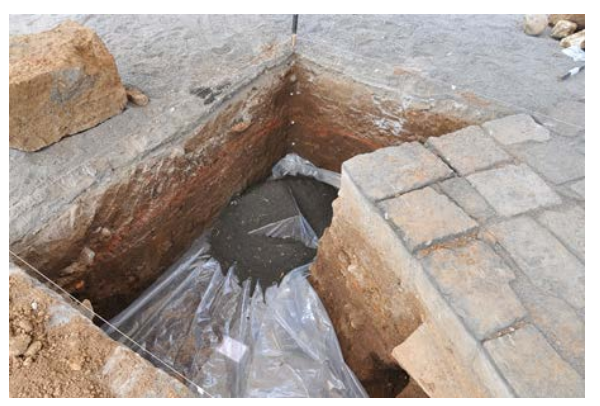

Gambar 22. Foto penutupan kembali kotak gali

Setelah proses ekskavasi selesai dilakukan langkah selanjutnya adalah penutupan kotak gali. Proses penutupan kotak gali dilakukan dengan meletakkan plastik bening di seluruh permukaan dasar kotak gali. di 
Tabel 6. Kemiringan bidang f-g dinding tenggara Candi Mendut

\begin{tabular}{|c|c|c|c|c|c|c|}
\hline \multirow[b]{2}{*}{ Bulan } & \multirow[b]{2}{*}{ Titik } & \multicolumn{4}{|c|}{ KEMIRINGAN } & \multirow{2}{*}{ Keterangan } \\
\hline & & & $\mathbf{X}$ & & $\mathbf{Y}$ & \\
\hline \multirow[t]{2}{*}{ Mei } & 'f & & $\left.\left.0^{\circ} 0\right)^{\prime}\right)^{\prime \prime}$ & + & $0^{\circ} 19^{\prime} 32^{\prime \prime}$ & \\
\hline & ' $\mathrm{g}$ & - & (0²’22” & + & 0²2’21” & \\
\hline \multirow[t]{2}{*}{ Juni } & 'f & + & $0^{\circ} 35^{\prime \prime}$ & + & $0^{\circ} 9^{\prime} 48^{\prime \prime}$ & \\
\hline & ' $\mathrm{g}$ & - & $00^{\circ} 43^{\prime \prime}$ & - & $0^{\circ} 1$ '0" & \\
\hline \multirow[t]{2}{*}{ Juli } & 'f & + & $00^{\circ} 5,53 \prime$ & + & $0^{\circ} 6{ }^{\prime} 10^{\prime \prime}$ & \\
\hline & ' $\mathrm{g}$ & - & 0`38’39”' & + & $0{ }^{\circ} 1^{\prime} 31^{\prime \prime}$ & \\
\hline \multirow[t]{2}{*}{ Agustus } & 'f & - & $0^{\circ} 9^{\prime} 36^{\prime \prime}$ & + & $0{ }^{\circ} 68^{\prime}$ & \\
\hline & ' $\mathrm{g}$ & - & 0¹'58” & + & $0 \circ 3 ’ 9 ”$ & \\
\hline
\end{tabular}

Keterangan:

Kemiringan $X=$ arah barat laut-tenggara

Kemiringan $Y=$ arah tmur laut-barat daya

Tanda $-=$ kemiringan ke arah dalam struktur

Tanda + = kemiringan ke arah luar struktur

bawah plastik bening diberikan lembar kertas berisi informasi tentang tanggal terakhir dilakukan ekskavasi, spit/kedalaman, nama kotak serta instansi yang melakukan ekskavasi. Hal ini dilakukan untuk mempermudah apabila di lokasi yang sama dilakukan penggalian arkeologi kembali.

\section{Pengukuran Kemiringan/ Pergerakan dari Penggelembungan Dinding}

Kondisi dinding bagian tubuh sisi timur Candi Mendut dengan kerusakan di beberapa bagian, menunjukkan data kerusakan berupa nat-nat batu yang merenggang dan keadaan lapis batu yang bergelombang serta dinding yang menggelembung. Inventarisasi kerusakan ini melalui pengamatan secara visual artinya dilakukan pengamatan langsung pada suatu objek. Pengamatan secara visual ini harus dilakukan secara detail agar mendapatkan data yang akurat dan valid, terutama pada titik-titik rawan yang mungkin terjadi perubahan struktur. Pengamatan secara visual ini sangat menguntungkan karena dapat mendeskripsikan secara nyata tentang kondisi suatu objek. Data pengamatan secara visual ini sudah barang tentu harus didukung oleh pengamatan yang lain sehingga dapat dilakukan analisa secara sempurna.

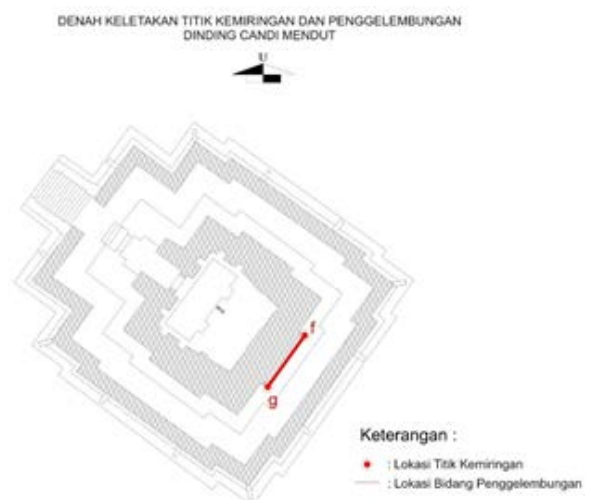

Gambar 23. Denah Candi Mendut

$$
\text { Pengukuran kemiringan/ }
$$
pergerakan dari penggelembungan dinding Candi Mendut sisi tenggara dilakukan menggunakan alat Laser Scanner. Pengumpulan data kemiringan dan dinding yang menggembung di Candi Mendut sisi tenggara diambil dengan menggunakan metode high digital dengan aplikasi 3D Laser Scanning 
yang langsung pada obyeknya di lapangan dari periode bulan Mei s.d. Oktober 2018. Berikut ini disajikan data tabel kemiringan sudut f-g dinding tenggara Candi Mendut dalam Tabel 6.

Dari hasil pengukuran yang dilakukan pada sudut $\mathrm{f}$ - g dinding tenggara Candi Mendut selama periode bulan Mei sampai dengan Agustus 2018, diperoleh data kemiringan dinding dalam kisaran angka < $0^{\circ} 40^{\prime} 00^{\prime}$. Berdasarkan Pedoman Teknis Pemeriksaan Awal Kerusakan Bangunan Akibat Gempa (PdT-11-2004-C), yang dibuat oleh Panitia Standarisasi Bidang Konstruksi dan Bangunan, mengacu pada Guidelines for Damages Inspection and Evaluation International Institute of Seismology and Earthquake Engineering, Ministry of Construction, Japan, Klasifikasi Stabilitas Bangunan berdasarkan nilai Kemiringan ( $(\Theta)$ adalah sebagai berikut:

- Ringan : $\Theta<3,6^{\circ}$

- Sedang : $3,6^{\circ}<\boldsymbol{\theta}<10,8^{\circ}$

- Berat : $10,8^{\circ}<\theta<21,6^{\circ}$

- Terguling : $\Theta>21,6^{\circ}$

Maka sudut $\mathrm{f}$ - $\mathrm{g}$ candi Mendut berdasar nilai kemiringan dinding yang diperoleh selama periode 4 bulan dapat dikatakan kecil meskipun data yang diperoleh dalam 4 bulan tersebut belum seragam.

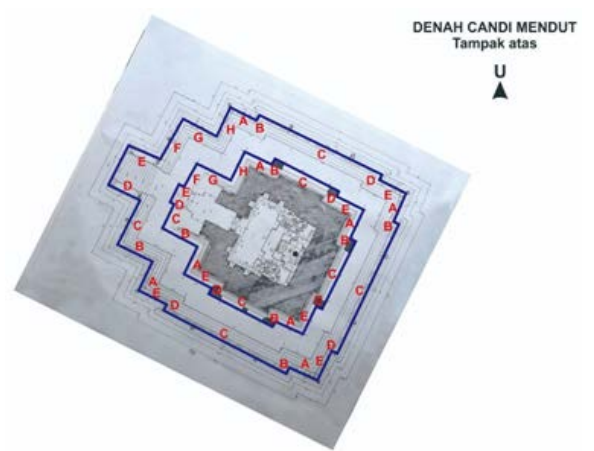

Gambar 24. Bidang pada Candi Mendut

Ada dua cara pengamatan penggelembungan dinding tenggara Candi Mendut yaitu pengamatan pada satu titik tengah bidang $\mathrm{C}$ dan yang kedua membuat grid hprisontal pada bidang $\mathrm{C}$ untuk pengamatan pergerakan penggelembungan. Tabel di atas adalah pengamatan pada titik sampel di tengah bidang C. Data hasil pengukuran dinding yang menggelembung dapat dilihat bahwa nilai penggelembungan diperoleh angka yang tidak signifikan, rata-rata terjadi penggelembungan $\leq 4 \mathrm{~mm}$. Adapun lokasi penggelembungan ini diambil pada posisi sebuah titik di tengah-tengah bidang $\mathrm{C}$ (di tengahtengah bidang relief).

Bidang C sisi tenggara Candi Mendut dibuat grid secara vetikal sebanyak 4 grid, pengamatan masing-

Tabel 7. Kemiringan bidang f-g dinding tenggara Candi Mendut

\begin{tabular}{|c|c|c|c|c|c|c|}
\hline \multirow[t]{2}{*}{ No } & \multirow{2}{*}{ Bidang } & \multirow{2}{*}{ Bulan } & \multicolumn{2}{|c|}{$\begin{array}{c}\text { Arah penggelembungan } \\
\text { (Meter) }\end{array}$} & \multirow{2}{*}{$\begin{array}{c}\text { Panjang } \\
\text { bidang } \\
\text { (Meter) }\end{array}$} & \multirow[t]{2}{*}{ Keterangan } \\
\hline & & & keluar (+) & $\begin{array}{c}\text { kedalam }(- \\
)\end{array}$ & & \\
\hline 1 & $\mathrm{C}$ & Mei & - & 0,002 & 5,31 & \multirow{4}{*}{$\begin{array}{l}\text { Posisi berada } \\
\text { ditengah-tengah } \\
\text { bidang relief }\end{array}$} \\
\hline 2 & $\mathrm{C}$ & Juni & - & 0,003 & 5,31 & \\
\hline 3 & $\mathrm{C}$ & Juli & - & 0,001 & 5,31 & \\
\hline 4 & $\mathrm{C}$ & Agustus & - & 0,004 & 5,31 & \\
\hline
\end{tabular}

Keterangan :

Tanda - = penggelembungan ke arah dalam struktur 


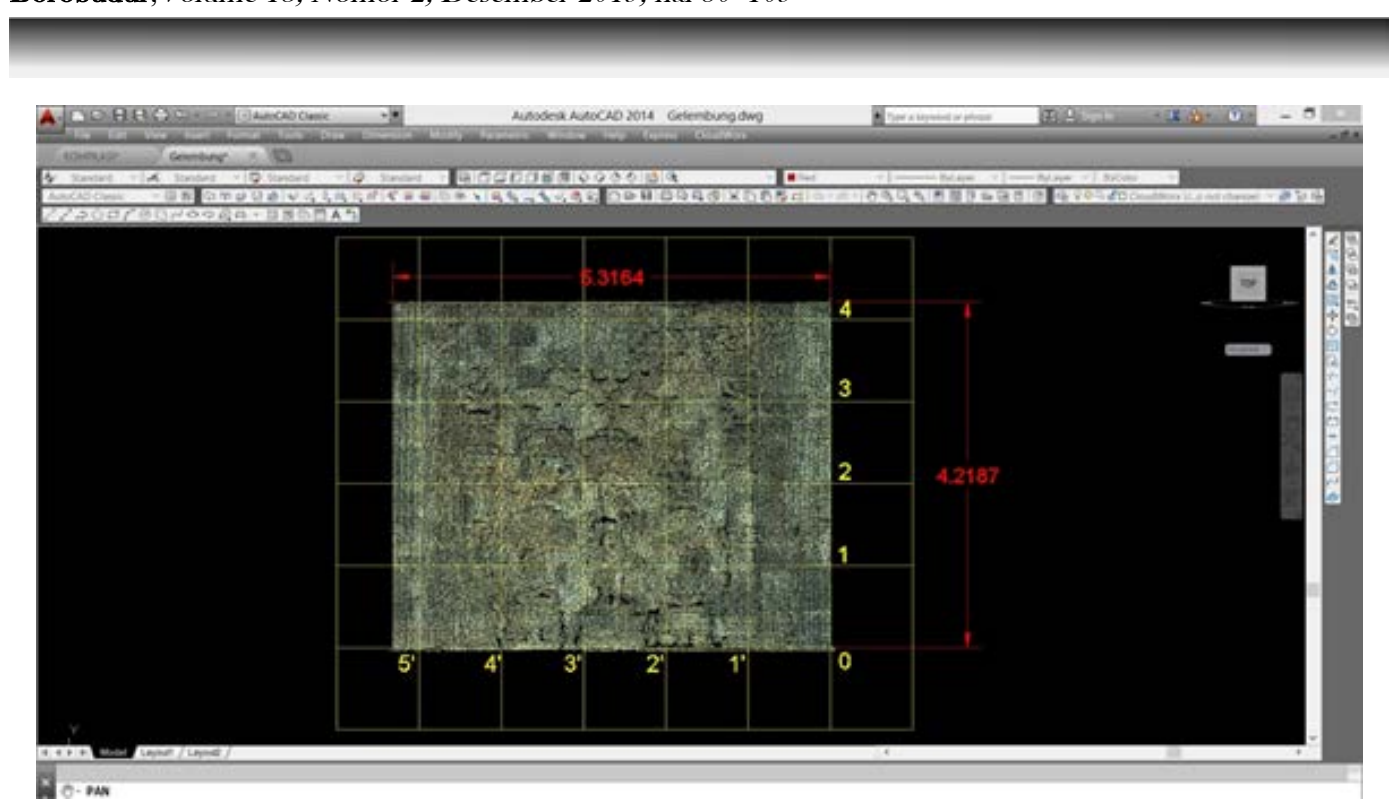

Gambar 25. Pembuatan grid horisontal pengamatan penggelembungan dinding tenggara
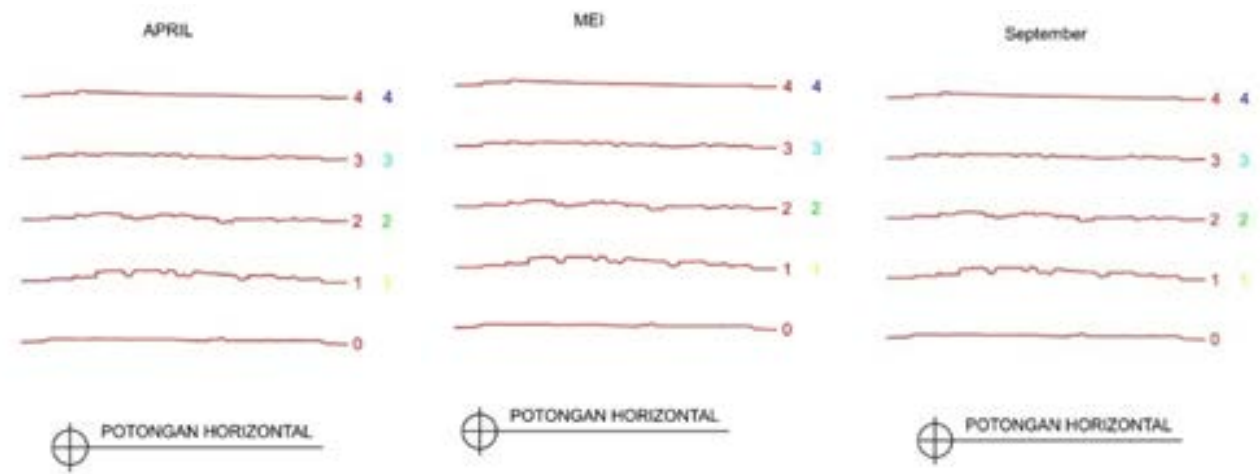

Gambar 26. Titik pengamatan penggelembungan (kiri) April 2018, (tengah) Mei 2018, (kanan) September 2018.

masing grid secara horisontal pada bulan April, Mei dan September pada Gambar 26.

Dari hasil gambar pertampalan ke empat grid selama waktu tiga bulan yaitu bulan April, Mei dan September 2018 didapatkan hasil tidak ada pergeseran letak titik pengamatan. Kedepan perlu dipertimbangan metode yang tepat dalam pengumpulan data penggelembungan dinding menggunakan Laser Scanner ini, sehingga data yang diperoleh dapat dibaca dan dianalisis dengan benar.

$$
\text { Adapun gambar hasil }
$$

perekaman data penggelembungan dinding Candi Mendut sisi tenggara menggunakan alat 3D Laser Scanner menunjukkan adanya bagian yang menggembung (Gambar 28).

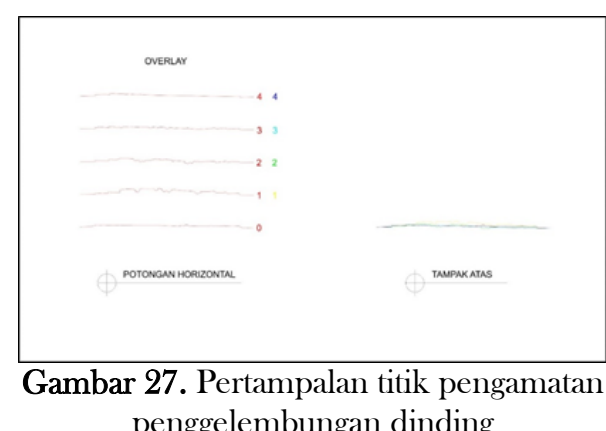
penggelembungan dinding 


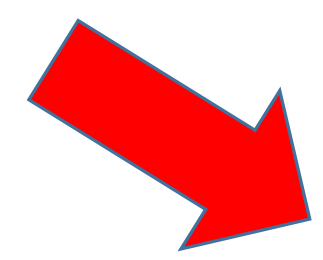

Tampak depan

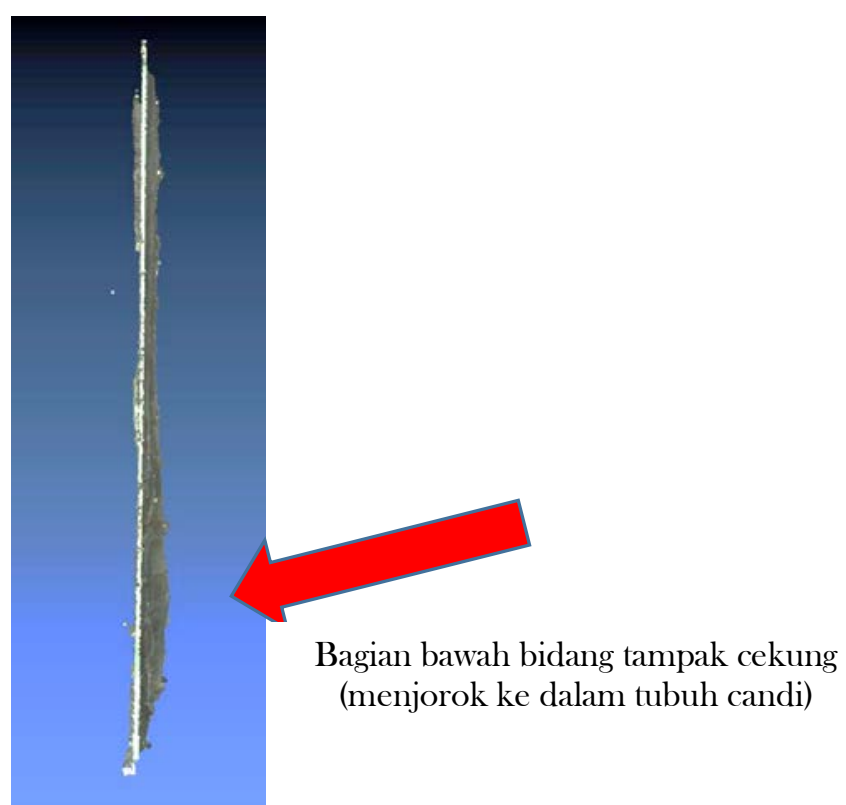

Gambar 28. Hasil perekaman 3D Laser Scanner
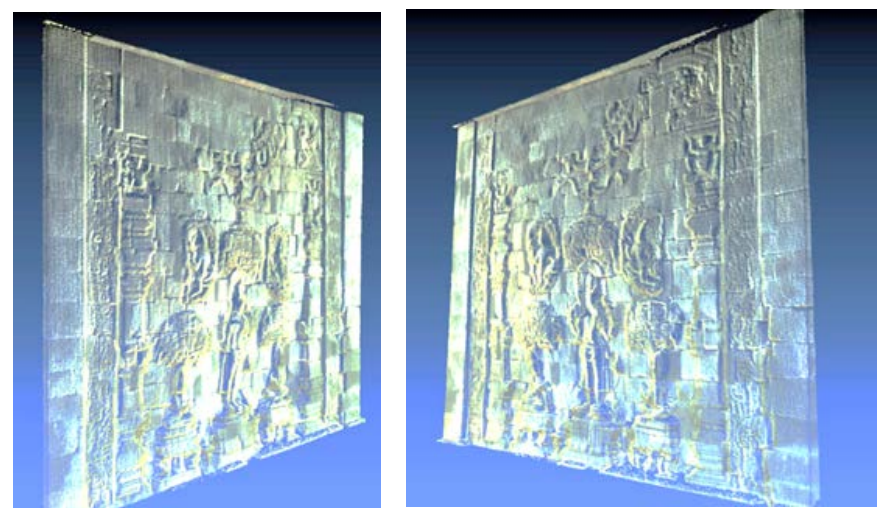

Gambar 29. Hasil perekaman 3D Laser Scanner

\section{Analisis Jenis Tanah di Sekitar Candi Mendut}

Analisis jenis tanah di sekitar Candi Mendut dilakukan dengan mengebor tiga titik dengan tujuan untuk melihat daya dukung tanah Candi Mendut terhadap bangunan di atasnya. Analisis ini dilaksanakan dengan bekerja sama dengan Laboratorium Mekanika Tanah, Universitas Islam Indonesia. Pengeboran tanah menggunakan alat khusus bor tanah dengan kedalaman mengeboran $4 \mathrm{~m}$ di masing-masing lokasi.

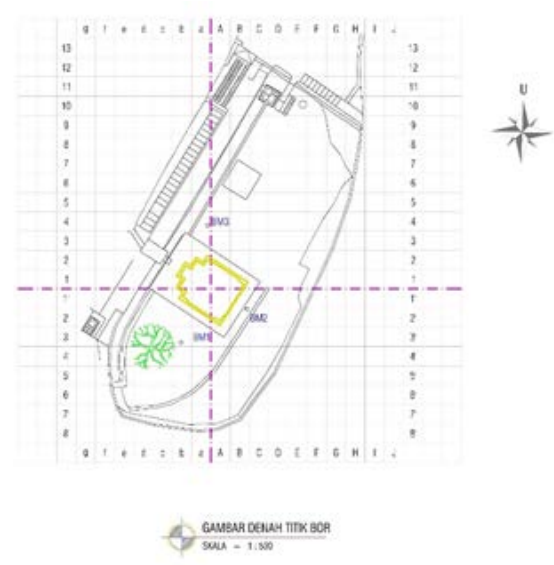

Gambar 30. Denah lokasi bor tanah di Candi Mendut 


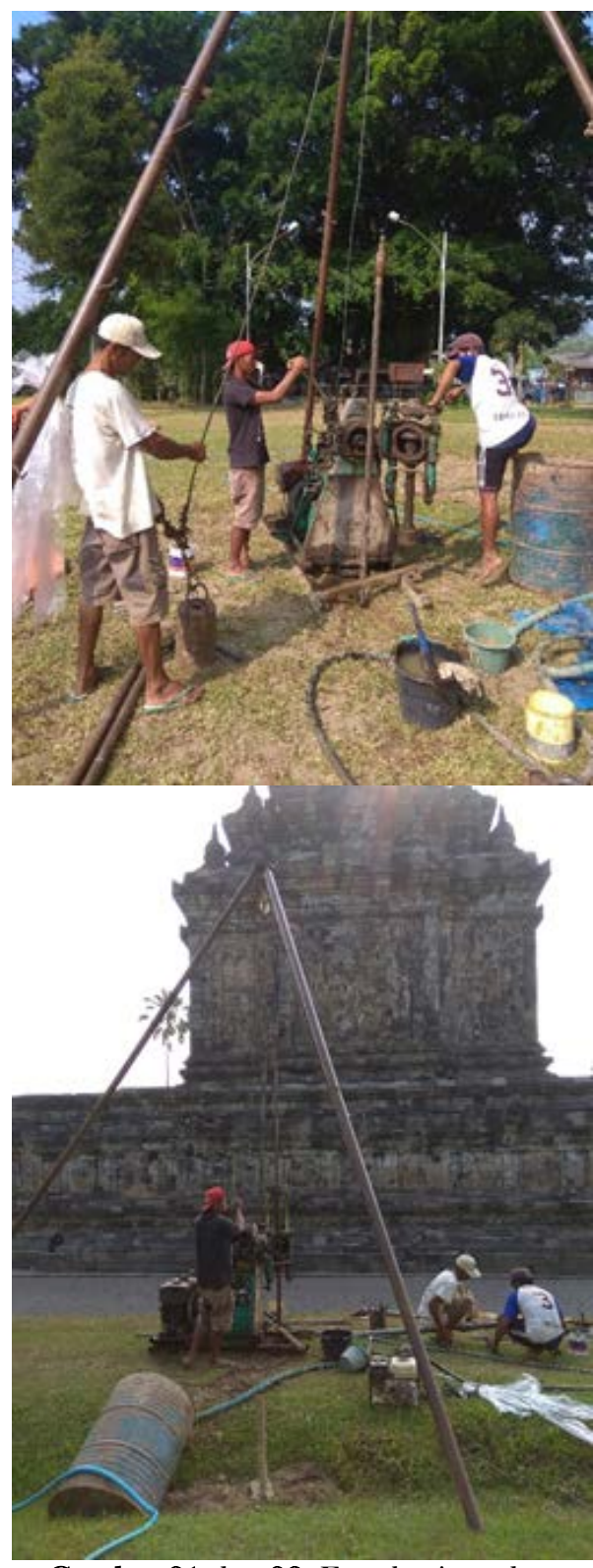

Gambar 31 dan 32. Foto kegiatan bor tanah di halaman Cand Mendut

Dari hasil analisis tanah didapatkan hasil sebagai berikut:

1. Pada kedalaman 0-1,3 m merupakan lapisan tanah pasir halus hingga sedang berlanau, berwarna coklat kehitaman dengan kepadatan sedang, sedangkan kedalaman 1,3-4,5 $\mathrm{m}$ berupa lanau berpasir halus, warna coklat, konsistensi sedang hingga kaku, dengan nilai SPT (Standard
Penetrating Test) berkisar antara 928.

2. Tanah di bawah Candi Mendut memiliki tingkat kepadatan sedang, hal ini dapat dilihat dari hasil uji SPT pada tiga titik dengan nilai SPT pada kedalaman 4 meter dengan rata-rata 17 (tanah dengan kepadatan sedang memiliki nilai SPT berkisar antara 10-30).

3. Dari hasil uji geser langsung diperoleh nilai sudut geser $29^{\circ}-33^{\circ}$, kohesi tanah (C) antara 0,20 - 0,22 $\mathrm{kg} / \mathrm{cm}^{2}=19,6 \mathrm{KN} / \mathrm{m}^{2}$ dan berat volume tanah (yb) sebesar 1,648 $\mathrm{g} / \mathrm{cm}^{3}=16,159 \mathrm{KN} / \mathrm{m}^{3}$.

Sudut geser merupakan sudut yang dibentuk dari hubungan antara tegangan normal dan tegangan geser dalam suatu material tanah, sebagai gambaran ketika kita mengambil sejumlah pasir dan kita tuang diatas permukaan, pasir tersebut akan membentuk sudut tertentu dengan permukaannya. Sedangkan kohesi tanah merupakan gaya tarik-menarik antara partikel tanah. Daya dukung ijin tanah (bearing capacity) adalah kekuatan tanah untuk menahan suatu beban yang bekerja padanya yang biasanya disalurkan melalui pondasi. Sedangkan daya dukung tanah batas (ultimate bearing capacity) atau q ult adalah beban maksimum persatuan luas dimana tanah masih dapat mendukung beban tanpa mengalami keruntuhan atau tekanan maksimum yang dapat diterima oleh tanah akibat beban yang bekerja tanpa menimbulkan kelongsoran geser pada tanah pendukung tepat di bawah dan sekeliling pondasi. Dengan menggunakan rumus-rumus Terzaghi (https://www.academia.edu/9895436/ 3_Daya_Dukung_Tanah). 
$q u l t=C \cdot N c+y b \cdot N q \cdot D f+0,5 \cdot y b \cdot B \cdot N y$

dengan : Df (kedalaman pondasi) : 0,2 meter $B$ (lebar pondasi) : 25,05 meter

Nilai factor Daya Dukung Terzaghi dengan sudut geser $(\Phi)=30^{\circ}$ yaitu :

- $\quad \mathrm{Nc}=37,16 \quad \mathrm{Nq}=22,46 \quad \mathrm{Ny}=$ 19,13 , untuk keruntuhan geser umum (General Shear Failure)

- $\mathrm{N}^{\prime} \mathrm{c}=12,37 \quad \mathrm{~N}^{\prime} \mathrm{q}=4,17 \quad \mathrm{~N}^{\prime} \mathrm{y}=$ 1,35 , untuk keruntuhan geser setempat (Local Shear Failure), dan $\mathrm{C}^{\prime}=2 / 3 \mathrm{C}=13,067$ $19,6 \mathrm{KN} / \mathrm{m} 2$ dan $\Phi^{\prime}=$ tan$1(2 / 3 \tan \Phi)=21,05^{\circ}$

Keterangan: $\mathrm{Nc}, \mathrm{Nq}$ dan $\mathrm{Ny}$ merupakan faktor daya dukung yang besarnya ditentukan dengan tabel faktor daya dukung Terzaghi (Chew et all. 2015).

- untuk (General Shear Failure)

$q$ ult $=. N c+y b \cdot N q \cdot D f+0,5 \cdot y b \cdot B \cdot N y$

$=(19,6 \times 37,16)+(16,159 \times$

$22,46 \times 0,2)+(0,5 \times 16,159 \times$

$25,05 \times 19,13)$

$=728,34+72,59+3871,80$

$=4.672,73 \mathrm{KN} / \mathrm{m} 2$

- untuk (Local Shear Failure)

$q^{\prime}$ ult $=$

$C^{\prime} \cdot N^{\prime} c+y b \cdot N^{\prime} q \cdot D f+0,5 \cdot y b \cdot B \cdot N^{\prime} y$

$=(13,067 \times 12,37)+(16,159 \times$

$4,17 \times 0,2)+(0,5 \times 16,159 \times$

$25,05 \times 1,35$ )

$=161,638+13,477+273,228$

\section{$=448,343 \mathrm{KN} / \mathrm{m} 2$}

Setelah daya dukung tanah batas (ultimate bearing capacity) atau q ult sudah didapatkan nilainya maka langkah selanjutnya dalah menghitung q (daya dukung ijin tanah), dengan runus:

$$
q=q \text { ult } / S f
$$

Dimana: $\quad$ Sf : faktor keamanan biasanya nilainya 3 .

Maka: $\mathrm{q}=4672,73 / 3=$

$1557,57 \mathrm{KN} / \mathrm{m} 2 \quad$ (General Shear Failure)

$\mathrm{q}^{\prime}=448,343 / 3=149,448$

KN/m2 (Local Shear Failure)

Selanjutnya untuk menghitung q candi (daya dukung candi) dibutuhkan data mengenai:

Luas alas Candi Mendut $=767,4 \mathrm{~m} 2$

Volume Candi Mendut $=3.938 \mathrm{~m} 3$

Berat jenis batu andesit $=2,7$ ton $/ \mathrm{m} 3$

Beban Candi keseluruhan =

volume $\mathrm{x}$ berat jenis batu andesit

$=3.938 \times 2,7$ ton

$=10.632,6$ ton $=104.199,48 \mathrm{KN}$

q candi = Beban Candi keseluruhan : Luas alas Candi Mendut

$=104199,48 / 767,40=$ 135,782

$\mathrm{KN} / \mathrm{m} 2$

Dari data hitungan di atas, dapat disimpulkan bahwa:

$135,782<1557,57 \mathrm{KN} / \mathrm{m} 2$ 


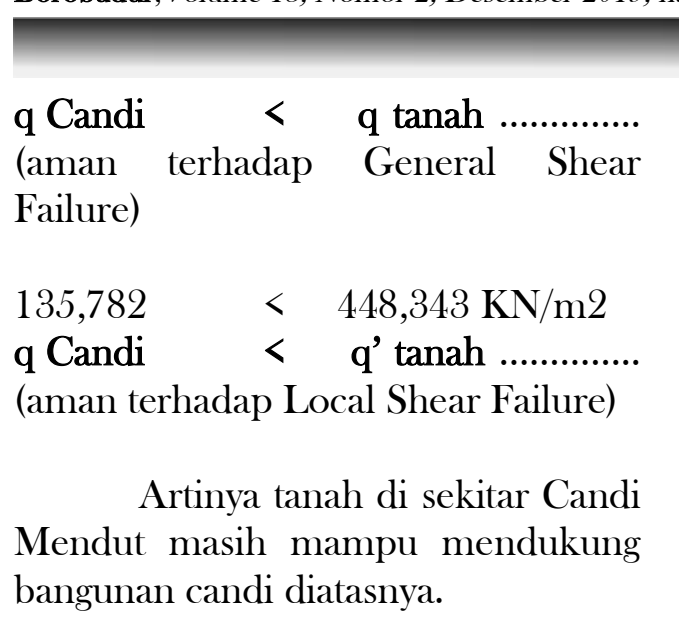

\section{Penyelidikan Foto-Foto Lama Candi Mendut}

Dikarenakan keterbatasan data-data pemugaran pertama yang dilakukan oleh pemerintah Belanda tahun 1900-an maka dilakukan pencarian foto-foto lama untuk mendapatkan tambahan informasi mengenai bangunan Candi Mendut. Foto-foto lama ini akan membantu memberikan informasi yang penting mengenai sejarah pemugaran yang telah dilakukan sebelumnya. Berikut akan ditampilkan hasil pencarian fotofoto lama yang diperoleh dari internet dari KITLV (Universitas Leiden, Belanda).

Gambar 33 dan 34 tampak foto Candi Mendut sebelum dilakukannya pemugaran pertama oleh pemerintah Belanda. Gambar 33 merupakan Candi Mendut tampak barat laut sedangkan Gambar 34 Candi Mendut tampak selatan. Arah hadap ini dapat ditentukan dari relief yang ada pada dinding candi. Foto diatas memperlihatkan atap candi yang mengalami kerusakan yang paling parah dibandingkan dengan bagian lainnya.

Gambar 35 memperlihatkan Candi Mendut yang sedang dipugar oleh pemerintah Belanda. Foto tersebut dipublikasi tahun 1898. Dari Gambar 35 dapat diketahui bahwa

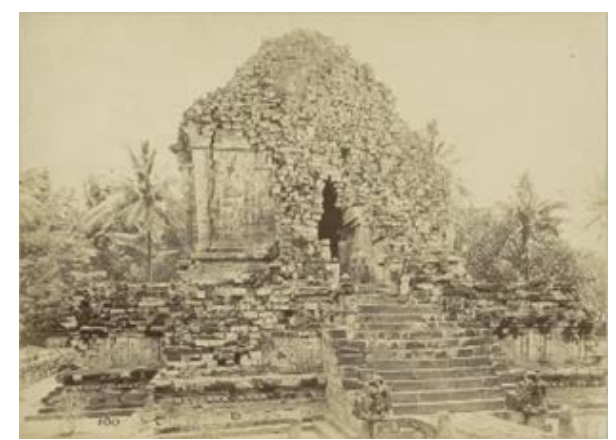

Gambar 33. Foto Candi Mendut yang dipublikasi tahun 1870-1910

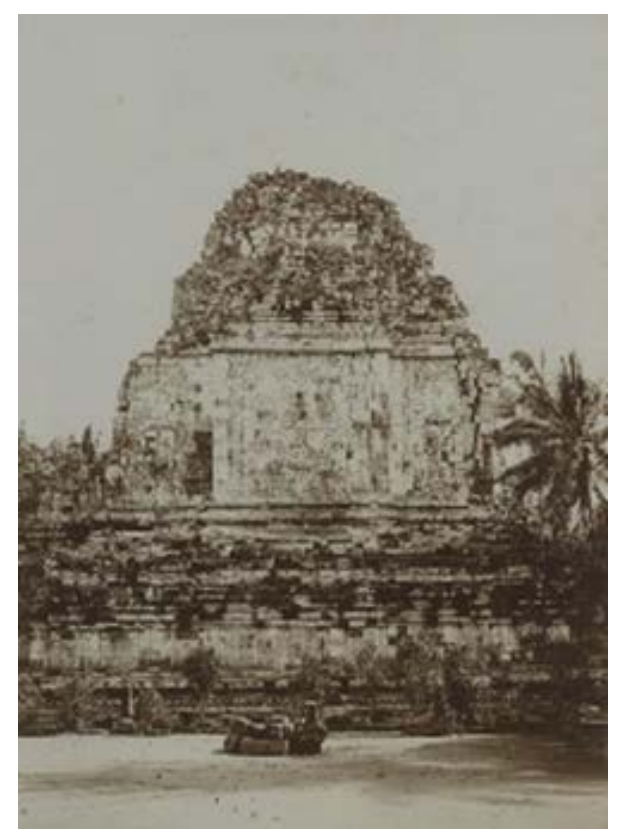

Gambar 34. Foto Candi Mendut yang dipublikasi tahun 1880

kegiatan pemugaran Candi Mendut telah dimulai pada kisaran tahun 1898. Berdasarkan foto tersebut terlihat kegiatan pemugaran dilakukan pada bagian tubuh dan atap Candi Mendut. Pada bagian tubuh candi diperbaiki terlebih dahulu baru kemudian bagian atap candi. Pada bagian atap candi khususnya sisi barat laut diatas pintu masuk bilik, dilakukan perbaikan dengan mengganti batu lama dengan batu baru. Hal ini terlihat dari bentuk susunan batu yang terlihat berbeda dari aslinya. Kegiatan perbaikan Candi 

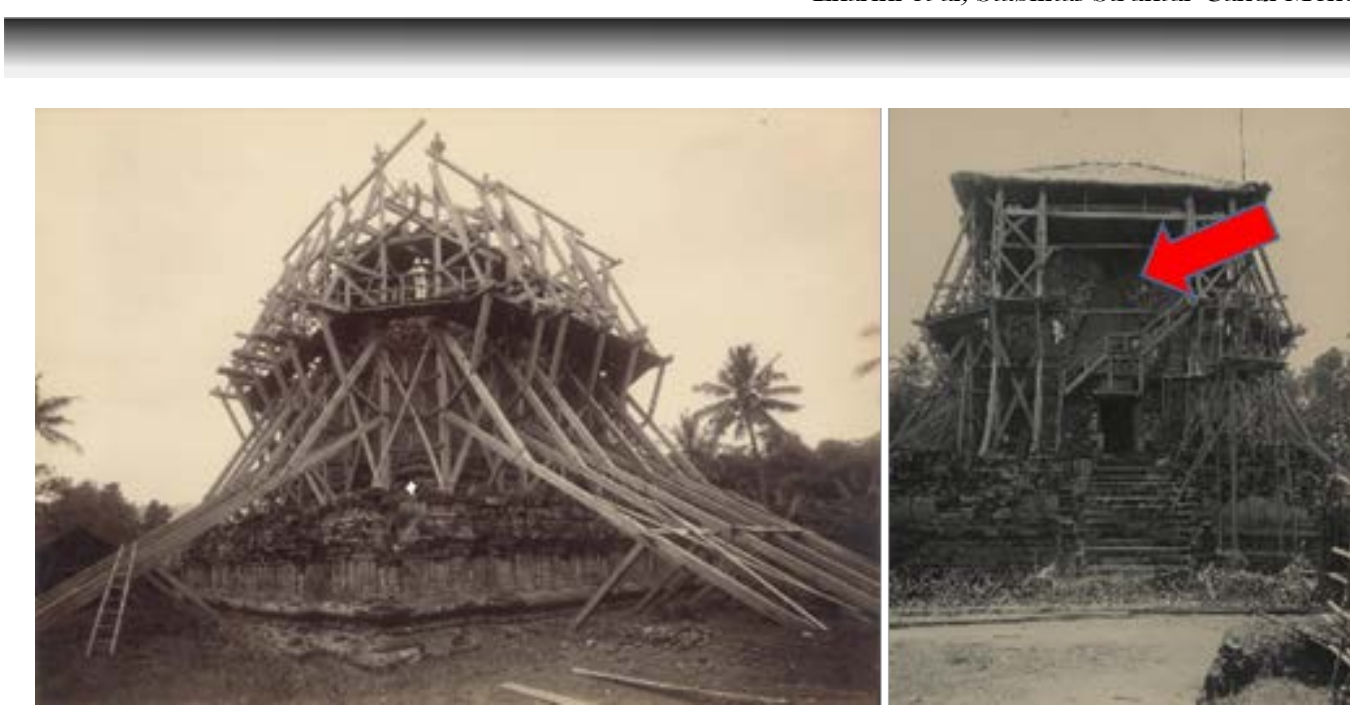

Gambar 35. Foto Candi Mendut yang dipublikasi tahun 1898

Mendut oleh pemerintah Belanda sepertinya tidak dilakukan pembongkaran penuh baik pada tubuh maupun atap candi namun hanya memperbaiki bagian yang mengalami kerusakan saja.

Gambar 36 memperlihatkan foto bagian atap Candi Mendut. Foto tersebut menunjukkan batu-batu baru hasil perbaikan yang dilakukan pada pemugaran pertama oleh Belanda. Dari foto tersebut terlihat bentuk dari batu-batu baru hasil pemugaran yang terlihat berbeda dengan lainnya. batubatu tersebut bentuknya lebih rapi dan presisi bentuknya serta susunannya sangat rapi. Foto berikutnya menunjukkan atap Candi Mendut pada bagian lain yang tidak diperbaiki. Susunan batunya seperti bentuk aslinya.

Apabila melihat atap bilik Candi Mendut sekarang terlihat bagian atap sisi barat laut atau di atas pintu masuk kondisi batuannya sangat berbeda dengan kondisi batu di tiga sisi lainnya. Pada atap sisi barat laut nampak warna batu yang berbeda yaitu lebih kehitaman dan bentuknya yang lebih rapi dan presisi susunannya. Batu-batu terebut adalah hasil

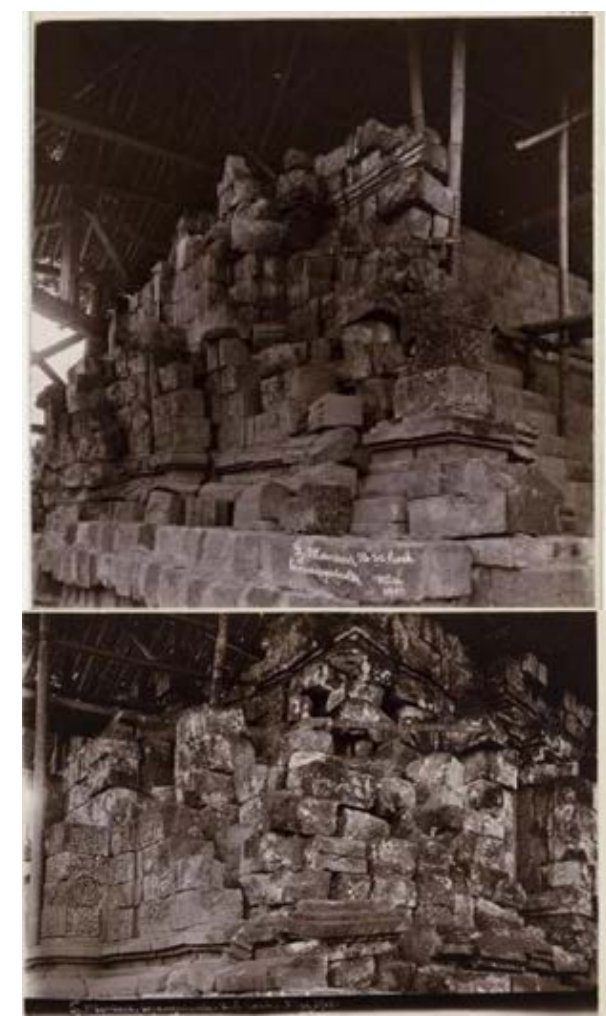

Gambar 36. Foto Candi Mendut bagian atap, diperbaiki pada bagian barat laut sedangkan bagian lain tetap seperti semula.

Foto dipublikasi tahun 1901 (Sumber: http://digitalcollections.universiteitleiden.nl)

pemugaran pertama oleh pemerintah Belanda.

Pencarian foto-foto lama melalui website KITLV juga menemukan foto Candi Mendut setelah selesai pemugaran. Ternyata 


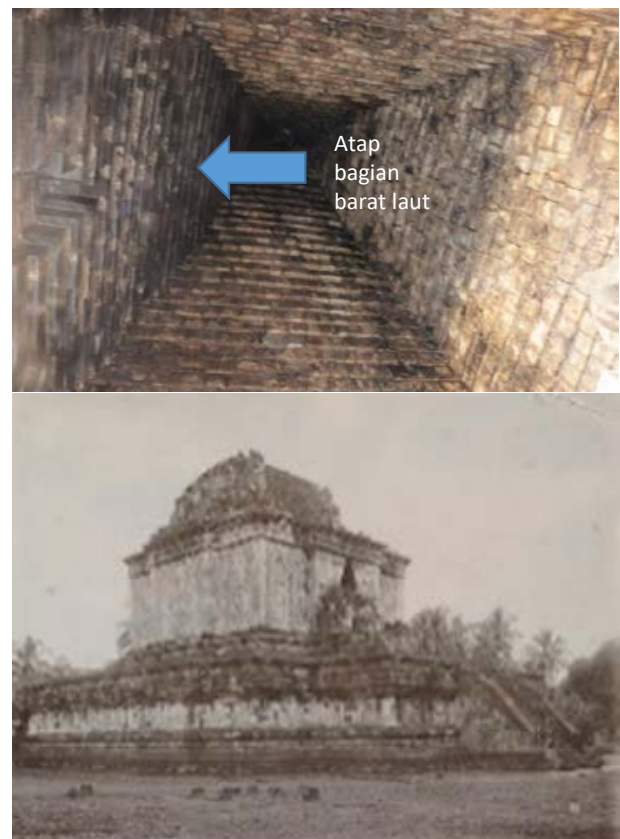

Gambar 37. Foto Candi Mendut bagian atap sisi barat laut

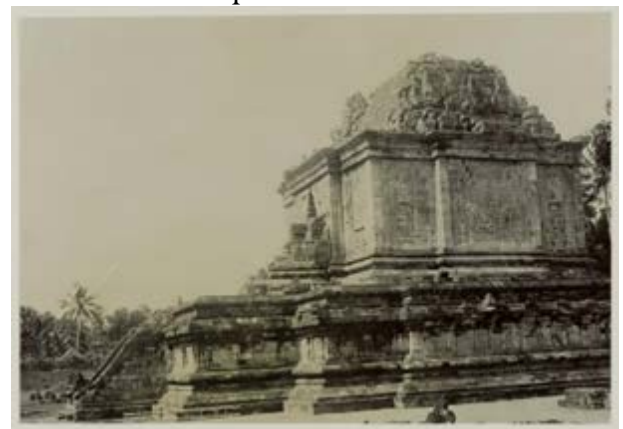

Gambar 38. Foto Candi Mendut yang dipublikasi tahun 1910

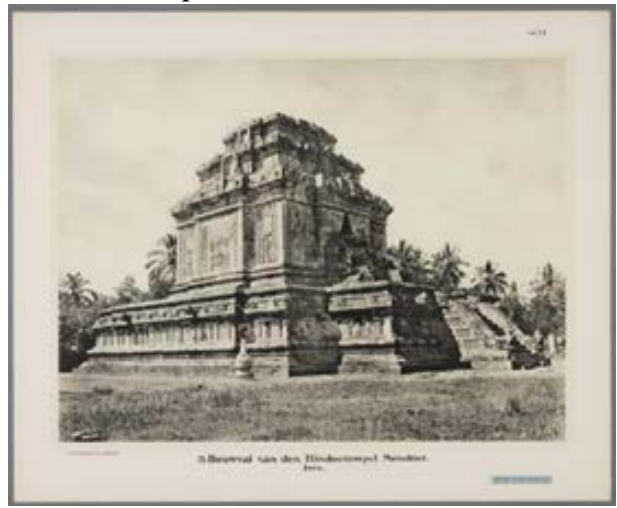

Gambar 39. Foto Candi Mendut yang dipublikasi tahun 1915

dari foto-foto tersebut terlihat bahwa kegiatan pemugaran yang dilakukan pemerintah Belanda tidak dilakukan

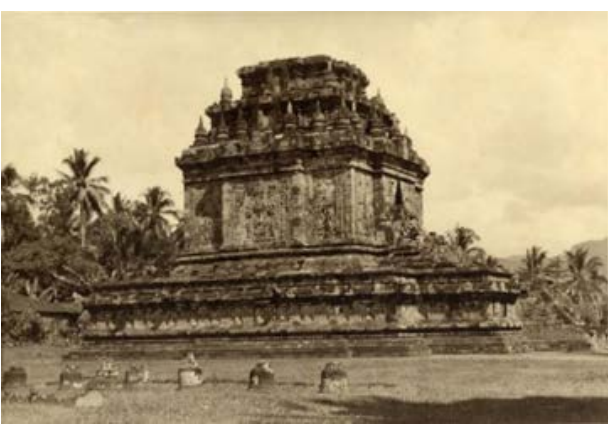

Gambar 40. Foto Candi Mendut yang dipublikasi tahun 1915

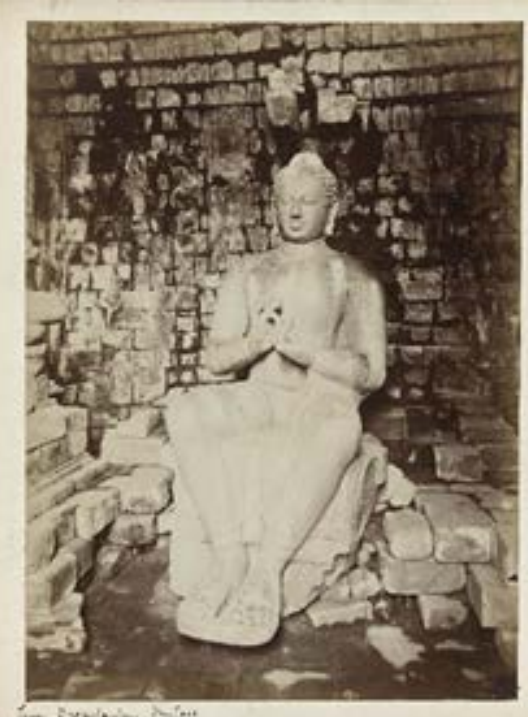

Gambar 41. Foto Arca Candi Mendut yang dipublikasi tahun 1850

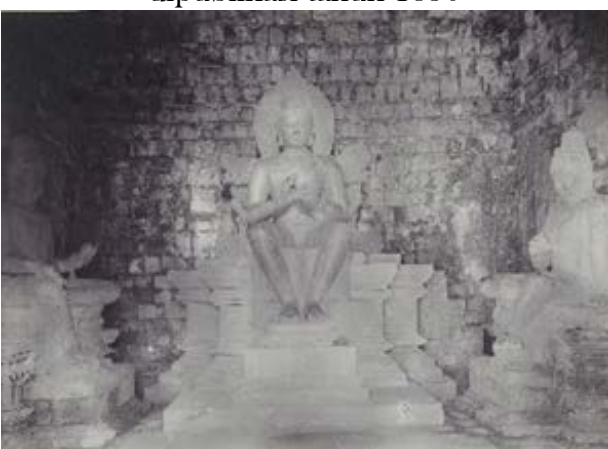

Gambar 42. Foto Arca Candi Mendut yang dipublikasi tahun 1915

dalam satu tempo pekerjaan namun bertahap.

Gambar 37 dan 38 adalah foto yang dipublikasi tahun 1910, terlihat pemugaran sudah selesai dilakukan, sudah tidak terlihat kayu-kayu penyangga kegiatan pemugaran. Pada 
atap candi sisi barat laut (diatas pintu masuk candi) terlihat susunan batu hasil pemugaran pertama. Pada saat itu batu luar pada atap sisi barat laut belum dikembalikan seperti semula, namun pekerjaan pemugaran sudah berhenti.

Gambar 39 adalah foto Candi Mendut yang dipublikasi tahun 1915. Pada foto terasebut terlihat pada bagian atap sisi barat laut batu luar telah dikembalikan pada posisi semula sehingga batu baru hasil pemugaran pertama sudah tidak terlihat.

Dalam foto tersebut stupa pada atap candi ternyata belum dipasang dan masih berada di bawah. Dari foto Candi Mendut yang dipublikasi pada tahun 1932 terlihat bahwa pada atap Candi Mendut telah terpasang stupa-stupa baik pada lantai 1 dan 2 (lihat Gambar 40). Sehingga kondisi Candi Mendut saat itu seperti yang terlihat pada kondisi eksisting sekarang ini.

Kondisi patung yang ada pada bilik Candi Mendut sebelum kegiatan pemugaran pertama juga terlihat mengalami kerusakan begitu juga kondisi lantai bilik. Pada Gambar 41 terlihat sebelum pemugaran arca pada bagian tengah Candi Mendut yaitu
Arca Dyani Buddha Cakyamuni atau Vairocana yang terlihat melesak ke bawah dan "praba" (lingkaran cahaya yang terdapat di belakang arca) yang sudah hilang. Pada pemugaran pertama dilakukan perbaikan dan hasilnya seperti tampak pada kondisi sekarang ini.

Pada Gambar 42 terlihat arca dan altar di bilik Candi Mendut telah diperbaiki, berikut juga "praba" di bagian belakang arca Dyani Buddha Cakyamuni atau Vairocana (arca bagian tengah). Selain foto pada bilik candi, dari penelusuran foto-foto lama juga didapatkan foto bagian struktur kaki candi yang memperlihatkan bahwa ternyata pada bagian kaki Candi Mendut terdapat struktur bata (lihat foto di bawah). Adanya struktur bata tersebut belum diketahui volume dan bentuknya, namun sekilas tidak berbentuk persegi namun pada bagian luarnya terdapat profil seperti profil pada batu luar sebuah candi.

Gambar 43 memperlihatkan adanya struktur bata pada kaki Candi Mendut. Foto tersebut dapat dikenali sebagai foto dari Candi Mendut karena adanya hiasan profil pada kaki candi yang berbentuk kotak-kotak kubus yang diindikasikan milik Candi Mendut. Foto tersebut dipublikasi
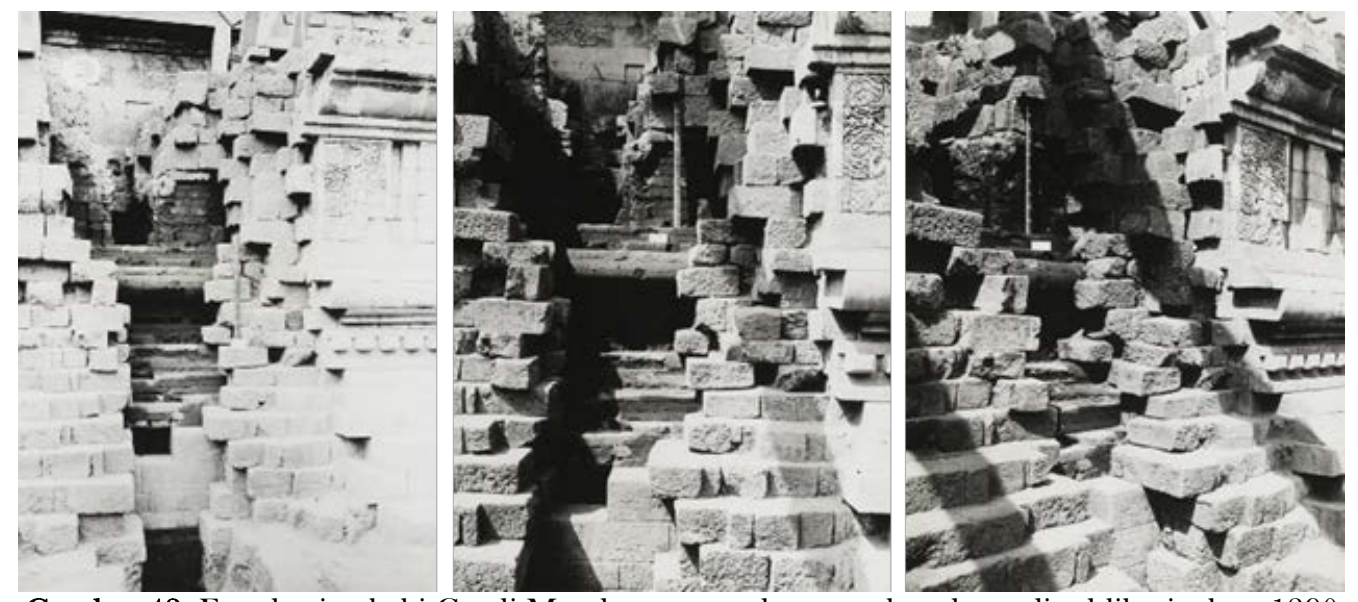

Gambar 43. Foto bagian kaki Candi Mendut yang terdapat struktur bata, dipublikasi tahun 1890 
inti yang melambangkan prakrti, pembangunan candi telah berpijak pada landasan yang kokoh menurut konsep keagamaan yang berlaku. Candi yang dibuat dengan cara ini telah memenuhi syarat sebagai tempat bersemanyamnya purusa (dewa) yaitu asas kejiwaan alam semesta.

Gambar 45 memperlihatkan bagian dalam kaki Candi Induk Sewu yang terbuat dari batu andesit yang terdapat susunan bata dengan ukuran utara selatan 5,3 $\mathrm{m}$ x barat timur 5,29 $\mathrm{m}$ dan tinggi $1,111 \mathrm{~m}$ atau 19 lapis bata. Konsstruksi bata ini berdiri tepat di tengah-tengah (pusat halaman satu). Mutu bata sangat baik dengan ukuran panjang $46 \mathrm{x}$ lebar $23 \mathrm{x}$ tebal $7 \mathrm{~cm}$. berdasarkan hasil analisis laboratorium Balai Konservasi Borobudur, bata Candi Induk Sewu

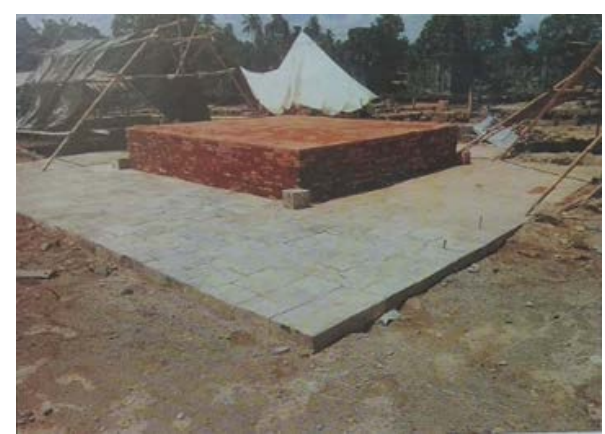

Gambar 45. Foto struktur bata di tengah susunan batu lapis 0 yang berdenah bujur sangkar pada Candi Induk Sewu

terdiri dari $30 \%$ pasir dan $70 \%$ lempung. Kondisi konstruksi bata masih sangat prima, keempat sisinya dibuat sangat halus (seperti diketam). Muka atasnya selain dibuat sangat halus, pemasangan batanya dibuat kait mengkait seperti pasangan batu andesit.

Jika dihubungkan adanya struktur bata di Candi Induk Sewu dengan struktur bata di kaki Candi Mendut adalah kedua candi tersebut sama-sama merupakan candi Buddha yang kemungkinan memiliki konsep keagamaan yang hampir sama. Struktur bata di Candi Mendut berada di kaki candi, namun memliki bentuk yang berbeda dari Candi Induk Sewu. Struktur bata di Candi Induk Sewu memiliki bentuk persegi, sedangkan di Candi Mendut muka bata memiliki porfil seperti halnya batu luar bangunan candi. Dari hasil foto lama tentang pembukaan/pembongkaran batu secara parsial pada kaki Candi Mendut terlihat bahwa secara sekilas susunan batanya tidak persegi namun memiliki profil layaknya batu luar sebuah bangunan candi. Apakah dulunya bata tersebut adalah sebuah bangunan candi kemudian ditutup batu andesit, masih belum diketahui. Selain itu volume dan bentuk dari susunan bata tersebut tidak bisa diketahui tanpa melakukan pembongkaran.

Dari hasil penelusuran fotofoto lama dari situs KITLV milik Universitas Lieden, Belanda terdapat beberapa hal yang dapat disimpulkan sementara yaitu:

1. Tidak/belum ditemukan foto tentang pembongkaran/pemugaran total bangunan Candi Mendut.

2. Kemungkinan pemugaran pertama oleh Belanda dilakukan secara parsial pada beberapa bagian saja yang mengalami kerusakan.

3. Terdapat beberapa tahapan pemugaran Candi Mendut yang dilakukan oleh Belanda.

4. Telah dilakukan pemugaran/pembongkaran/

perbaikan pada bagian atap dan tubuh serta bagian bilik Candi Mendut.

5. Terdapat struktur bata pada bagian dalam kaki Candi Mendut. 


\section{FGD (Focus Group Discussion)}

Tujuan dari kegiatan ini adalah untuk mencari informasi penting dalam pemantauan stabilitas sebuah bangunan candi. Beberapa rekomendasi penting hasil kegiatan FGD ini adalah membuat standar/pedoman kemiringan dinding sebuah bangunan candi, alat pengukuran disarankan menggunakan GPS Geodetik yang lebih canggih sehingga datanya bisa akurat, titik pengamatan untuk monitoring kemiringan ataupun deformasi merupakan titik awal yang sangat penting sehingga harus dipertimbangkan masak-masak dimana akan ditempatkan titik pengamatan monitoring dan perlu pembuatan sistem monitoring deformasi baik vertikal maupun horisontal yang mewakili bagian kaki, tubuh dan atap candi. Sehingga apabila ada pergerakan dapat diketahui bangian mana yang mengalami pergerakan. Rekomedasirekomendasi ini sangat penting dalam menganalisis stabilitas struktur bangunan candi.

\section{SIMPULAN DAN SARAN}

Beberapa simpulan yang dapat diambil dari hasil kajian ini adalah berdasarkan hasil analisis data monitoring pengukuran kemiringan dinding candi dan kerenggangan nat batu candi didapatkan hasil bahwa untuk kemiringan dinding candi terjadi variasi pergerakan ke arah tubuh dan luar candi maksimal sebesar 4 detik, sedangkan untuk kerenggangan nat batu selama tahun 2017-2018 terjadi kecenderungan kerenggangan nat yang semakin besar pada titik pengamatan. Hal ini harus dipantau secara intensif dan diwaspadai sehingga kondisi bangunan candi terpantau. Berdasarkan data pengukuran kualitas batu penyusun bangunan Candi Mendut menggunakan cepat rambat gelombang ultrasonik didapatkan hasil bahwa kondisi batu luar dan bilik Candi Mendut masih memiliki kualitas yang sama baiknya dengan batu yang ada di Candi Borobudur, namun perlu penanganan konservasi parsial pada beberapa blok batu yang mengalami kerusakan.

Dari hasil ekskavasi pada stuktur pondasi bagian tepi Candi Mendut terlihat pondasi candi hanya 1 lapis batu dengan ketebalan $20 \mathrm{~cm}$, dan di bawahnya dijumpai lapisan mortar yang diduga buatan Belanda sewaktu memugar tahun 1900an. Untuk sisi candi yang lain dan pondasi yang menyangga tubuh candi belum diketahui apakah juga memiliki struktur pondasi yang sama atau tidak. Dari hasil pengukuran kemiringan dinding dan batu yang menggelembung pada bidang $\mathrm{C}$ sisi tenggara candi, menunjukkan terjadinya nilai kemiringan ataupun penggelembungan yang kecil namun harus dipantau secara terus menerus. Belum adanya pedoman mengenai kemiringan dinding yang susuai untuk bangunan candi. Sedangkan dari hasil analisis tanah di sekitar Candi Mendut didapatkan hasil bahwa daya dukung tanah Candi Mendut masih bagus untuk mendukung bangunan candi diatasnya.

Untuk menganalisis kondisi stabilitas struktur khususnya Candi Mendut, tentu saja kurang valid apabila hanya dilakukan dengan data selama tahun berjalan 2018, apalagi dengan keterbatasan data-data referensi tentang pemugaran sebelumnya. Yang dapat dilakukan 
adalah data yang diambil tahun 2018 dijadikan baseline atau data dasar untuk kegiatan monitoring pemantauan kedepan sehingga bisa didapatkan data periodik dan diketahui arah perkembangannya.

Untuk pemantauan atau monitoring stabilitas struktur Candi Mendut direkomendasikan beberapa hal yang harus dilakukan yaitu:

1. Membuat standar pedoman kemiringan, penggelembungan dan retakan batu pada dinding Candi Mendut dengan melakukan pengukuran secara periodik selama waktu tertentu sehingga didapatkan standar pedoman kemiringan, penggelembungan dan retakan batu pada dinding candi.

2. Diperlukan pengukuran deformasi vertikal dan horisontal Candi Mendut untuk memantau pergerakan bagian pondasi, kaki, tubuh dan atap bangunan candi.

3. Perlu dilakukan sistem registrasi per batu di Candi Mendut dalam sehingga pemantauan kerusakan baik material maupun struktural dapat terpantau.

4. Perlu dilakukan sistem monitoring digital khususnya dalam pengamatan kerusakan dan pelapukan batu Candi Mendut 


\section{DAFTAR PUSTAKA}

Anom, IGN. (1992). Candi Sewu: Sejarah dan Pemugarannya. Bagian Proyek Pelestarian/Pemanfaatan Peninggalan Serah dan Purbakala Jawa Tengah

Anom, IGN. (1992). Keterpaduan Aspek Teknis dan Aspek Keagamaan Dalam Pendirian Candi Periode Jawa Tengah (Disertasi). Yogyakarta: Universitas Gadjah Mada.

Balai Konservasi Borobudur. (2017). Laporan Monitoring Candi Borobudur, Candi Mendut, Candi Pawon, dan Kawasan Cagar Budaya Borobudur. Magelang, Jawa Tengah

Chew Y.M, et al. (2015). The Affect of Soil Variability on The Ultimate Bearing Capacity of Shallow Foundation. Journal of Engineering Science and Technology. Special Issue on ACEE 2015 Conference, August (2015): 1-13.

UNESCO. (2017). Technical Mission to Borobudur World Heritage Site in Indonesia October 29th to November 8th 2017. Germany: Hans Leisen and Ester von Plehwe-Leisen

\section{Website}

(https://www.academia.edu/9895436/3_Daya_Dukung_Tanah) diunduh tanggal 15 Oktober 2018

(https://digitalcollections. universiteitleiden.nl) diunduh Bulan April 2018. 